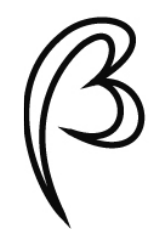

Bureau d'économie théorique et appliquée

\title{
«The Power of Big Data: Historical Time Series on German Education »
}

\section{Bureau d'Économie}

Théorique et Appliquée

BETA - UMR 7522 du CNRS

\section{BETA Université de Strasbourg}

Faculté des sciences économiques et de gestion

61 avenue de la Forêt Noire 67085 Strasbourg Cedex

Tél. : +33 (0)368 852069

Fax : +33 (0)368 852070

Secrétariat : Géraldine Del Fabbro g.delfabbro@unistra.fr

\section{BETA Université de Lorraine}

Faculté de droit, sciences

économiques

et de gestion

13 place Carnot C.O. 70026

54035 Nancy Cedex

Tél. : +33(0)3 72742070

Fax : +33 (0)3 72742071

Secrétariat : Sylviane Untereiner sylviane.untereiner@univ-lorraine.fr

\author{
$\underline{\text { Auteurs }}$ \\ Document de Travail n $2017-10$
}

Claude Diebolt, Gabriele Franzmann, Ralph Hippe, Jürgen Sensch

Mars 2017

http://www.beta-umr7522.fr 


\title{
The Power of Big Data: Historical Time Series on German Education
}

\author{
Claude Diebolt, Gabriele Franzmann, Ralph Hippe, Jürgen Sensch*1
}

Diebolt, Claude, BETA/CNRS, Université de Strasbourg, 61 avenue de la Forêt Noire, 67085 Strasbourg cedex, France.

E-mail: cdiebolt@unistra.fr

Franzmann, Gabriele, GESIS Leibniz Institute for the Social Sciences, Team: Data Linking and Data Security (DLS), Unter Sachsenhausen 6-8, 50667 Cologne, Germany. E-mail: gabriele.franzmann@gesis.org

Sensch, Jürgen, GESIS Leibniz Institute for the Social Sciences, Unter Sachsenhausen 6 - 8, 50667 Cologne, Germany.

Hippe, Ralph, European Commission, Joint Research Centre (JRC), Directorate for Growth and Innovation, Human Capital and Employment Unit, Via E. Fermi 2749, 21027 Ispra, Italy.

E-mail: ralph.hippe@ec.europa.eu.

\begin{abstract}
Numerous primary investigators collected and processed long termed time series on German educational statistics in the context of their studies. As a result there are a multitude of quantitative empirical studies. On the one hand there is the project group on German Educational Statistics. ${ }^{2}$ Its projects were targeted at describing and analysing the long-term structural changes of the German educational system on a broad empirical and statistical basis. On the other hand there are comprehensive data compilations of individual research projects, focusing on a wide variety of special educational research topics. The online database 'histat' provides central digital access to these datasets on German educational history. Currently, it offers more than 120,000 long-term time series on the German educational system for a period of 200 years. The striking size of the database shows its key importance for researchers in the field of education. Thus, this paper aims to provide useful insights into the background of the database, the special characteristics of the data compilations and their analytical potential. Additionally, examples are given of how the data have already been used by researchers.
\end{abstract}

\section{Keywords}

Big Data, Cliometrics, Demography, Education, Germany.

\section{JEL Codes}

$\mathrm{C} 81, \mathrm{C} 82, \mathrm{C} 83, \mathrm{I2}, \mathrm{J} 11, \mathrm{~N} 33, \mathrm{~N} 34$.

\footnotetext{
* Disclaimer: The views expressed are purely those of the writers and may not in any circumstances be regarded as stating an official position of the European Commission.

${ }^{1}$ We thank Professor Dr. Rainer Metz for his helpful comments.

${ }^{2}$ The project group was supported by the DFG from 1977-2015.
} 


\section{Introduction}

This paper presents a new and very large database of more than 120,000 long-run time series on education in Germany. The data has been compiled in the context of a comprehensive data collection program on German education history, which was promoted by the German Research Foundation $(D F G)^{3}$ on the one hand and in connection with individual research projects on the other hand. Today, the access to the database is possible on the GESIS ${ }^{4}$ online platform 'histat' (Historical Statistics) $)^{5}$.

The impressive size of the database shows its key importance for researchers in the field of education. Researchers are not obliged to research individual printed sources and publications anymore. In consequence, it is clear that 'histat' presents a huge progress in its field in the sense that it considerably reduces the time spent for the analysis of German historical education. Historical education statistics for Germany have never been that easily accessible at the fingertips of the research community. As education is connected to many other scientific areas, it can also be considered as an excellent tool for the larger research community.

The collected data of the studies offered via 'histat' covers a period of 200 years. The data are about the institutional development of the German educational system and the development of educational participation. The statistical reports start with the higher school system and the higher educational system of the German Empire. Then, the educational institutions of the two systems of the early Federal Republic of Germany and the former German Democratic Republic are treated statistically. Finally, the educational system of the unified Germany in the borders after $3^{\text {rd }}$ October 1990 is reported. Data on a variety of institutions, their students and teachers are included, beginning with the school system, continuing with institutions of vocational education, and finally closing with higher educational institutions. Additionally, studies with national accounts data, public budgets and the share on expenditure on education are available. Population data also facilitate the calculation of pupils and students rates.

Therefore, the aim of this paper is to provide insights into the background of the database, describe relevant technical issues and give examples of how it has already been used by researchers.

\footnotetext{
${ }^{3}$ Deutsche Forschungsgemeinschaft.

${ }^{4}$ GESIS-Leibniz Institute for the Social Sciences is an infrastructure institution that is funded by the federal government of Germany and individual German states. As a service and research institute, GESIS provides research-based infrastructure services in the areas of empirical social research, archiving, documentation and information retrieval. See: http://www.gesis.org/en/home/.

${ }^{5}$ See website http://www.gesis.org/histat/. The data offered via the research and download platform histat (Historical Statistics) are freely available. The use of histat is free of charge. Under the leadership of Professor Rainer Metz and with the considerable contribution of Dipl.-Soz. Jürgen Sensch, the histat database was developed with long time series for studies of the social and economic history of Germany. Some use was made of the already available concepts by Ulrike Albrecht and Andreas Kunz (1990), however these were amended and extended. Subsequent programmatic implementation and support was provided by the company DataQuest in Göttingen (http://www.data-quest.de). The project was funded by the GESIS-Leibniz Institute for the Social Sciences. Further information on the database histat in: Franzmann, Gabriele (2015): The OnlineDatabase histat as an Example for Research-Promoting Infrastructures for Studies in Quantitative Historical Research. In: Économies et Sociétés. Cahiers de l'ISMÉA. Série: histoire économique quantitative. AF no 50, Juin 2015. Pp. 821-856.
} 
In line with these objectives, the paper is structured as follows: first, we begin by presenting the data inventory. In particular, we explain the context of the data collection and indicate the types of analysis the collected data are suitable for. The question of the analytical strengths and weaknesses of each individual data compilation will be addressed. Furthermore, we discuss how the presented data compilations can be linked to each other. Then, we briefly describe the integration and the supply of the data under a unified user interface via the search and download system 'histat'. Third, we present a selection of recent important research articles employing the new datasets. Finally, we give a short forecast on future development possibilities.

\section{Histat data on the history of education in Germany}

The data stock on education history in histat comprises both data compiled in the framework of the DFG promoted research group on qualification crisis and published as the comprehensive "Data Handbooks on Historical Education Research" and data of individual studies, which have been gathered by the primary investigators to answer a special research question.

\subsection{DFG supported "Data Handbooks on Historical Education Research"”}

The "Data Handbooks of Historical Education Research" comprise 15 volumes. Thirteen volumes have been published in the framework of the DFG supported research group on Qualification Crisis (abbreviation: QUAKRI), whereas two issues are still in preparation (i.e. Volumes IV and V). Furthermore, the issue of Volume II, Part 3 (Social History and Statistics on Girls' School System) has not been imported into histat due to its data structure, which does not fit to histat's time-series structure. Volume III (Differentiation and Integration of Lower Schools in Germany, 1800-1945) has been published in September 2016 and thus the study has not yet been archived and processed. Therefore, histat currently includes the data of 11 volumes.

Each of the published volumes is dedicated to a particular segment of the German educational system and to a certain period within the last 200 years. The primary objective of this DFG Priority Program is to provide a database, reaching far back in German history for future research. Therefore, the volumes of the Data Handbooks offer a comprehensive collection of long time series on historical German educational statistics. The data have been collected from contemporary official statistics sources, and then been processed in a user-friendly way and documented in detail. The data compilations are accompanied by notes on the data collection methodology. Research have to reorganise the original data material to fit the structure of the histat database. Indeed, this can be a labour-intensive and time-consuming task. For example, the time series of the Data Handbooks cover a long period which is characterized by major changes and turning points of the educational system. In consequence, scientists have to cope with breaks in the development of the educational system and with changes in the statistical methods of data collection. Where possible, calculations and estimations have been made in order to obtain continuous and comparable time series. In such

\footnotetext{
${ }^{6}$ The description of the development of the Research Program "Data Handbooks on German Educational History" draws on the following article: Peter Lundgreen (2006): Historische Bildungsforschung auf statistischer Grundlage. Datenhandbücher zur deutschen Bildungsgeschichte. In: Zeitschrift für Erziehungswissenschaft, Vol. 10, No. 7/2006, p. 5-13.
} 
cases, detailed notes on the employed methodologies are provided. Otherwise, the historical data have been represented in accordance with the source and are accompanied by detailed sourcecritical annotations. Finally, these volumes document statistically the development of educational institutions and their use by pupils and students, the number of graduates, and the development of the teaching personnel. Moreover, there is additional information about the population. They cover the geographic area of the German Empire, Prussia, the early Federal Republic of Germany, the former German Democratic Republic, and Germany, partly subdivided in regions.

The origin and background of the research group was the discussion on qualification crisis theory in the educational sector. The term 'qualification crisis' is attributed to the work by Detlef K. Müller', who developed and analysed this theory in his dissertation "Social Structure and the School System". The term describes a process of devaluation of qualifications achieved in the educational system, due to the increased attendance of higher education institutions and the corresponding surplus of educational achievements (D. K. Müller, 1977, p. 26-28). In the context of the qualification crisis theory, a functional connection between the following lines of development is assumed: attendance or use of educational institutions, the discussion conducted within society about the use of the educational institutions, and political attempts to control the educational system. Above all, it is possible to empirically measure the situation of overcrowding in educational institutions or the change to a lack of pupils, students and graduates. As a multidimensional analytical model, questions arose from the qualification crises theory that stimulated the expansion of research to the long time period from 1800 to the present, as well as to all segments of the educational system. Therefore, the intention grew to conduct a precise statistical analysis of pupil and student flows, as well as the social-statistical classification of pupils and students stretched from the time of the German Empire to the present Federal Republic and the former German Democratic Republic (cf. P. Lundgreen, 2006: p. 5-6).

As Peter Lundgreen described in his overview of the origins and the resulting research work in his paper "Historical educational research on a statistical basis" ${ }^{8}$, the two most important centres of research on the qualification crises were located in Bochum (D. K. Müller) and Göttingen (H.G. Herrlitz, H. Titze, P. Lundgreen), each of which had clearly distinct empirical areas. While the area of higher and middle schools was addressed in Bochum, the institutions of higher education ${ }^{9}$ formed the focus of interest in Göttingen. In each case the temporal starting point was the German Empire, to which the period up to 1945 was then added. The final phase was then the temporal expansion of the research activities to the present. Regional statistics were also collected with the aim to illustrate regional development processes.

In the following, let us now present each of the 11 volumes, providing information on their contents and other relevant background information.

\footnotetext{
${ }^{7}$ Müller, Detlef K. (1977): Sozialstruktur und Schulsystem. Aspekte zum Strukturwandel des Schulwesens im 19. Jahrhundert. Göttingen, Vandenhoeck \& Ruprecht.

${ }^{8}$ Lundgreen, Peter (2006): Historische Bildungsforschung auf statistischer Grundlage. Datenhandbücher zur deutschen Bildungsgeschichte. In: Zeitschrift für Erziehungswissenschaft, Vol. 10, No. 7/2006, p. 5-13.

${ }^{9}$ Universities, university of applied sciences, etc.
} 


\subsubsection{The higher education studies in Prussia and in the German Empire}

In the first volume of the data handbook the authors Titze, Herrlitz, Müller-Benedict and Nath dedicate themselves to higher education studies in Prussia and Germany. Data Handbook Volume I, Part 1 and Part 2, records attendance at colleges and universities statistically. Volume 1, "College Studies in Prussia and Germany $1820-1944^{\prime 10}$, comprises the historical student statistics in long time series, in which university attendance was documented at the level of the German and Prussian state. These are long time series on students by type of higher education institution, ${ }^{11}$ disaggregated by sex and citizenship. The same statistics are reported for selected academic subjects. ${ }^{12}$ The data are completed by further detailed information on the students. ${ }^{13}$

The second volume "Growth and Differentiation of German Universities 1820 to $1944{ }^{14}$ contains data on long-term university attendance at the level of the individual universities or colleges. As in the case of the first volume, the information on students are disaggregated by the studied subject, gender, and citizenship from the early 19th century until the end of World War II. These time-series on individual universities level are documenting the long-term process of institutional differentiation of the German higher education institutions.

Additionally, the compilation is completed by population data, disaggregated by sex and by age.

The authors followed three principles in the data-collecting process to provide a comprehensive data compilation for further research. First, long-term time series have priority over differentiated representation for short periods. Second, absolute values have priority over percentage calculations. Third, redundant data are to be avoided (Titze, Hartmut et al., 1987, S. 16).

Potential uses and limitations of the data compilation: The data enable researchers to analyse the socalled overcrowding crisis by using the example of higher education and of selected academic professional groups. New insights into growth processes are also possible. The student flows can be analyzed according to the territories of the German Empire and Prussia as a whole and by individual university or by subject. Furthermore, some ratios on students relative to the population can be calculated. However, interesting characteristics of students such as the age, the school-leaving

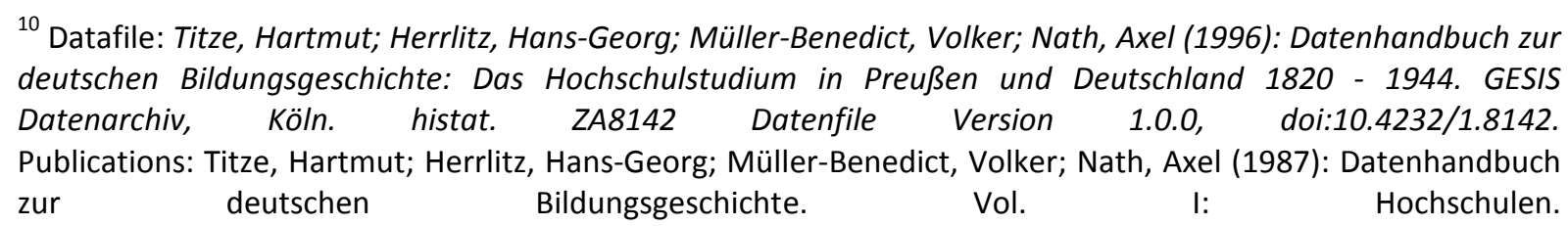
Teil 1: Das Hochschulstudium in Preußen und Deutschland 1820 - 1944. Göttingen: Vandenhoeck \& Ruprecht.

${ }^{11}$ During the time of the German Empire, a distinction was made between the following higher education institutions: universities, technical universities, commercial colleges, philosophical-theological colleges, pedagogical academies, veterinarian universities, agricultural universities, forestry colleges, and mining academies.

${ }^{12}$ The academic subjects which are in the focus of the Data Handbook Vol.I part 1, are theology, law, health science, cultural studies, mathematics and natural sciences, economics and agricultural and forest sciences.

${ }^{13}$ Information are on age, type of school-leaving qualification, social origin or the father's occupation, received benefits, and faculty exchanges.

${ }^{14}$ Datafile: Titze, Hartmut; Herrlitz, Hans-Georg; Müller-Benedict, Volker; Nath, Axel (1996): Datenhandbuch zur deutschen Bildungsgeschichte: Das Hochschulstudium in Preußen und Deutschland 1820 - 1944. GESIS Datenarchiv, Köln. histat. ZA8142 Datenfile Version 1.0.0, doi:10.4232/1.8142. Publication: Titze, Harmut et al. (1995): Datenhandbuch zur deutschen Bildungsgeschichte. Vol. I: Hochschulen. Teil 2: Wachstum und Differenzierung der deutschen Universitäten 1820 - 1944. Göttingen: Vandenhoeck \& Ruprecht. 
qualification, the father's occupation as an indicator of social background, as well as the received benefits, are not available for individual universities in histat. These students' characteristics are only available for students of all universities and university types in Germany and in Prussia, but here again for each faculty subject. Finally, the religious affiliation has been gathered and presented in the printed Data Handbook, Volume I, Part 1. Yet this variable is not contained in the data compilation imported into histat. In the printed data handbook, this variable is documented comprehensively, without going down on the level of single academic subjects. Therefore, the printed data handbook has to be consulted for this variable.

\subsubsection{The higher school system of the German Empire and of Prussia}

The Data Handbook Volume II, Part $1^{15,16}$ and Part $2^{17,18}$, edited by Müller, Zymek and Herrmann, addresses the subject of grammar schools and intermediate schools. Regional statistics were collected in order to illustrate regional development processes. The first part documents the development of the higher school system in the states of the German Empire from the time of the institutionalization of the modern educational system at the beginning of the 19th century to the end of the Second World War. The number of schools in the German Empire as a whole and the number of individual school types ${ }^{19}$ is specified as well as the number of pupils by school types. The second part contains the basic and structural data of the higher schools for the male population in the state of Prussia and in the Prussian provinces.

\footnotetext{
15 "Social History and Statistics of the School System in the States of the German 'Reich', 1800-1945"

${ }^{16}$ Datafile: Müller, Detlef K.; Zymek, Bernd (2006): Datenhandbuch zur deutschen Bildungsgeschichte. Vol. II: Höhere und mittlere Schulen. Teil 1. Sozialgeschichte und Statistik des Schulsystems in den Staaten des Deutschen Reiches, 1800-1945. GESIS Datenarchiv, Köln. histat. ZA8240 Datenfile Version 1.0.0, doi:10.4232/1.8240.

Publication: Müller, Detlef K.; Zymek, Bernd; Herrmann, Ulrich (1987): Datenhandbuch zur deutschen Bildungsgeschichte. Vol. II: Höhere und mittlere Schulen. Teil 1: Sozialgeschichte und Statistik des Schulsystems in den Staaten des Deutschen Reiches 1800-1945. Göttingen: Vandenhoeck \& Ruprecht.

17 "Higher secondary Education for the male population in the Prussian state and in the Prussian Districts, 1832 to 1941 "

${ }^{18}$ Datafile: Müller, Detlef K.; Hermann, Ulrich G.; Zymek, Bernd (2011): Die Höheren Schulen für die männliche Bevölkerung im Staat Preußen und in den preußischen Provinzen 1832 - 1941. GESIS Datenarchiv, Köln. histat. ZA8478 Datenfile Version $\quad 1.0 .0, \quad$ doi:10.4232/1.10312.
} Publication: Müller, Detlef K.; Hermann, Ulrich G.; Zymek, Bernd (2003): Datenhandbuch zur Deutschen Bildungsgeschichte. Vol. II: Höhere und mittlere Schulen. Teil 2: Regionale Differenzierung und gesamtstaatliche Systembildung. S. 149-461: Die Höheren Schulen für die männliche Bevölkerung im Staat Preußen und in den preußischen Provinzen 1832 - 1941. Göttingen: Vandenhoeck \& Ruprecht.

${ }^{19}$ There is a distinction between Gymnasiale Anstalten (Anstalten=institutions), realgymnasiale Anstalten, and institutions without the subject Latin called lateinlose Anstalten. Gymnasiale Anstalten are institutions teaching one modern language and the two old languages Latin and Greek. They offer a humanistic education. The curriculum of Realgymnasiale Anstalten includes the teaching of two modern languages and Latin as an old language. The word portion 'Real' refers to the teaching of scientific subjects. On this basis a further differentiation is made into so called Vollanstalten and Proanstalten. Vollanstalten are schools with an extended school attendance between six to nine years. Proanstalten require a school attendance between four and seven years. This leads to the following school types: Gymnasiale Vollanstalten, Gymnasiale Proanstalten, Realgymnasiale Vollanstalten, Realgymnasiale Proanstalten, Lateinlose Vollanstalten, and Lateinlose Proanstalten. 
Once again, schools and pupils by school-types are provided in long time series. Furthermore, the religious denomination by school-type is given for the census years between 1880 and 1915 . Additionally, the distribution of the pupils over the classes is reported. The number of high school graduates of the so called 'Gymnasiale Vollanstalten' are included by their age (in absolute figures) and by their career aspirations or their desired course of study (in percentage). Data tables with pupil ratios by school type and with quotas of school graduates are also reported. Finally, the data compilation provides information on the population development of the German Empire and its states for the years $1830,1850,1870,1890$, and 1910 . However, this table is not disaggregated by sex or by age groups.

Knowledge of the historical circumstances is important to understand the statistics because national and regional characteristics of the historical German education system have been extremely diverse. In addition, there has been an enormous structural change of the different types of schools. There is, for example, no useful general definition of the type of school names for the 19th and early 20th centuries. Neither the differentiation of the educational institutions into the criteria, 'low', 'medium', and 'higher', nor the classification into elementary school (Grundschule, Volksschule), middle school, intermediate school, or secondary school (Realschule), and high school, grammar school (Gymnasium) describe the school types at that time correctly. The structural transformation of the educational institutions is described by the authors as a process of increasing system formation in schools, universities and within the professional career paths (Müller, Detlef K. / Zymek, Bernd, 1987, p. 12). Therefore, long time series were not available in the source material. In consequence, categories and classifications had to be developed by the authors during the data collection process. Particular attention was paid to the following criteria for the aggregation of different school types over time: first, the comparability between the school-types and school-type-aggregations, and second, content consistency of school type designations. The authors aim to describe the development of the school system also at the regional level. In this context a particular serious problem is the different quality of statistics in the individual German states. While Prussia had sophisticated statistics on the education system, the statistics of the other German states were significantly poorer in their information density and differ in their reporting systems. Therefore, the authors had to limit their data collection for the other German States on basic information. Nevertheless, the authors were able to collect an extensive amount of data.

Potential uses and limitations of the data compilation: The first part of the data allows an analysis of the structural development and growth of the German higher school-system for a period of 150 years. It is possible to analyse the differentiation of school types and the development of the school attendance by school type. Especially the second part of the Data Handbook enables a reconstruction of the development of the population's participation in the higher education system. Unfortunately, as there is no information of the pupils' social background, the participation cannot be described in terms of the social structure. Where the quality of the source allowed it, information on religious denomination of the pupils has been collected. This information could be gathered mainly in the case of Prussia. The second issue of the data compilation ${ }^{20}$ goes in this case beyond the first issue ${ }^{21}$,

\footnotetext{
${ }^{20}$ In histat Study-No.: ZA8478.

${ }^{21}$ In histat Study-No.: ZA8240.
} 
because the religious denomination for male pupils of higher education is reported here on the level of Prussian single states and provinces for each school type. ${ }^{22}$

\subsubsection{Academic careers in Prussia and in the German Empire between 1850 and 1945}

In addition, Müller-Benedict highlights the career stages of selected academic professions in Prussia and Germany until 1945 in Volume VI: "Academic Careers in Prussia and in Germany 1850 to 1945"23. The members of the examined academic professions are recorded statistically according to, among other things, age structure and doctorates completed at universities. The focus of interest is on members of six professions from the mid- $19^{\text {th }}$ century to the mid- $20^{\text {th }}$ century: Protestant theologians, lawyers, doctors, higher-level teachers, engineers, and chemists. The important stages during the course of the academic careers were documented. Therefore, in particular the duration of study, examination rates and results of examinations, doctorates, employment rates, age structure of the academic employees etc. were collected in the framework of the project. The ratio of the number of the respective academic employees per 10,000 inhabitants is also reported. Additionally, four time-series on the population of the German Empire and of Prussia, and for Prussia by sex are provided from 1815 to 1945 . However, information on the social origin of the employees could not be gathered by the author.

The time-spam of the data compilation (1850 to 1945) was chosen according to the time periods of the other Data Handbook projects. ${ }^{24}$ Furthermore, new occupations arose in the middle of the $19^{\text {th }}$ century by creating standardizations, establishing professional associations and differentiating separate career stages. Finally, another reason for the chosen time-span is that since 1850 the data situation of the universities improved, thanks to the influence and commitment of the Prussian Ministry of Education and Arts (Müller-Benedict, V., 2008: p. 18).

In this context, it is important to note that the territory of investigation underwent significant border changes. This leads to breaks in the time series. The first period is about Prussia within the German Confederation, which was a loose confederation of states between 1815 and 1866 . The second

\footnotetext{
${ }^{22}$ In this context it is useful to know, that at the time of the German Empire school types of general upper secondary education had been differentiated into two parts. The humanistic grammar schools (Gymnasien, Gymnasiale Anstalten) had been for a long time the only school type with the authorization to issue an university entrance qualification. Thus, Gymnasiale Anstalten (humanistic grammar schools) and universities were closely tied together. Furthermore, pupils with successfully concluded higher school education on a grammar school had access to professions of the state sector. On the other hand new requirements on the abilities of school graduates developed in the context of industrialization and the rising economic society. Companies had to recruit young talents for their leading positions from school graduates of very different education institutions. Some higher educational school types emerged with the development of the commercial and industrial sector. However, despite the offered higher school education, this part of school types had no authorization to issue an university entrance qualification. This led to disputes over the authorisation system at the end of the $19^{\text {th }}$ century. It was a great achievement at the time of the German Empire to integrate the huge variety of higher educational institutions - higher school types and higher education institutions (universities, etc.) - into an entire system, in which they are functuionally related to each other (Titze, H. et al., 1995: p. 19).

${ }^{23}$ Datafile: Müller-Benedict, Volker (2008): Akademische Karrieren in Preußen und Deutschland 1850 bis 1945. GESIS Datenarchiv, Köln. histat. ZA8274 Datenfile Version 1.0.0, doi:10.4232/1.8274. Publication: Müller-Benedict, Volker, with Jörg Janssen and Tobias Sander (2007): Datenhandbuch zur Deutschen Bildungsgeschichte. Vol. VI: Akademische Karrieren in Preußen und Deutschland 1850-1945. Göttingen: Vandenhoeck \& Ruprecht.

Note that Volumes III to $\mathrm{V}$ of the data handbook have not been published and thus cannot be described yet.

${ }^{24}$ Volume I, and Volume II on the period of the German Empire.
} 
period relates to the period between 1866 and 1870, the time of the North German Confederation, which was a military confederation of 18 states (Müller-Benedict, 2008, S. 18). Third, as a consequence of the military conflict between the North German Confederation and France the southern German states Baden, Hesse, Wuerttemberg, and Bavaria joined to the North German Confederation on January 1871, and the German Empire was founded. Fourth, the Treaty of Versailles after the First World War stipulates that the German Empire (1871 to 1918) lost AlsaceLorraine, West Prussia and Danzig, the Memel region, large parts of Poznan, and the Saar region. Finally, for the period of the Third Reich (nazi period) the collected data refer to the territory, called by the national socialists 'altes Reich' (old Empire). The so called old Empire relates to the German Empire in the borders of 1937.

Potential uses and limitations of the data compilation: The data for the six academic professions has been collected because these professions had been selected by most of the students until the beginning of the Second World War. The careers differ by occupational status, by field of activity and by the degree of their professionalization. Therefore, statistical comparisons are possible. Furthermore, the Data Handbook VI immediately follows the Data Handbook I, part 1 and part 2, in which the university attendance and the study progress is reported for German and Prussian universities (Müller-Benedict, 2008, S. 17). Hence, the first stage of academic careers, which is the first university examination (Data Handbook I), can be linked to the information on further academic career stages. The age structure of the employees working in the academic professions is reported for the single professions in different categories. The most differentiated time series on age are reported for theology. The age is reported by individual years by nine German states for this profession, whereas the age information is reported in less detail for medical science, chemists, engineers and technicians. This fact makes comparisons between the employees of these professions according to the age structure more difficult. The population data are not disaggregated by age. Additionally, information on the social origin is not available. Therefore, it is difficult to make statements on the degree of social openness of the society at the period of investigation. The development of professional associations is only given for two professional groups. In this case information on the number of members is available for associations of technical professions and of chemical professions. Professional associations had a considerable influence on the development of the academic professions.

\subsubsection{General secondary schools in the Federal Republic of Germany from 1949 to 2010}

Moreover, the timeframe was also expanded in many projects from 1945 to the present. Peter Lundgreen completed the historical education statistics for the former Federal Republic of Germany and for Germany after unification on October 3rd 1990, by compiling several extensive Volumes of the Data Handbook.

With the collaboration of Helmut Köhler the Data Handbook Volume $\mathrm{VII}^{25}$ deals with the "General secondary schools in the Federal Republic of Germany from 1949 to 2010", and it addresses different

25 Datafile: Köhler, Helmut; Lundgreen, Peter (2014) Allgemein bildende Schulen in der Bundesrepublik Deutschland 1949 - 2010. GESIS Datenarchiv, Köln. histat. ZA8570 Datenfile Version 1.0.0, doi:10.4232/1.12378.

Publication: Lundgreen, Peter; Köhler, Helmut; with Thomas Rochow and Jürgen Schallmann (2014): Vol. VII: 
aspects of the German educational system during the period of the Federal Republic of Germany. The published time series have three substantial areas of focus: (1) the institutions of the educational system are described; ${ }^{26}$ (2) school participation is presented; (3) finally, information on graduates has been collected. ${ }^{27}$

The official statistics differentiate among 15 school types of general education. The authors decided to use a summarized classification, in which 8 school types are distinguished: the so called Volksschulen ${ }^{28}$; primary or basic schools ${ }^{29}$; secondary general schools ${ }^{30}$; intermediate schools or middle schools ${ }^{31}$; grammar schools ${ }^{32}$; and comprehensive schools ${ }^{33}$. In addition, information on special schools has been collected. Training institutions for further education (= Fortbildungseinrichtungen) are belonging to the eighth school type, which is dealt with in this data compilation. This school type contains different types of evening schools and colleges, for example to catch up a school graduation, or simply for further education (Lundgreen, P.; Köhler, H., 2014, p. 17).

Potential uses and limitations of the data compilation: The institutional breakdown of the German educational system and its changes in the course of time can be described on the basis of the data at hand. In particular, there are time series data available dealing with the institutional breakdown of schools by school types and German federal states. Statistics on schools in general, private schools, and number of classes are reported. Therefore, different tendencies in the development of schools by regions and school types can be described and analysed (Lundgreen, P.; Köhler, H., 2014, p. 38). The statistical definition of a school is based on the educational goal and qualification level of the educational institutions. However, there are different survey methods of the single federal states statistics. Changed categorizations of school types and different allocations of schools to school types have a direct effect on the statistical results and make comparisons between regions and for longer time periods more difficult. Furthermore, the separate statistics on basic schools, secondary general schools, and orientation levels (grades 5 and 6) at the national level are available only from 1986 onwards because the collected data of the individual German federal states could not be subdivided into these categories for the time period before 1986. Therefore, a part of significant and sudden changes in the time series can be reduced to changed data collection methods (Lundgreen, P.; Köhler, H., 2014, p. 38). Statistics on the number of classes per school type and individual federal

Allgemein bildende Schulen in der Bundesrepublik Deutschland 1949 - 2010. Göttingen: Vandenhoeck \& Ruprecht.

${ }^{26}$ Development of the school structure, extension of the schools.

${ }^{27}$ School-leavers according to type of qualification and school type.

${ }^{28}$ Volksschulen = elementary or primary schools from grade 1 to grade 8 , provides its pupils with a basic general education to enable them to attend a vocational school. This school type existed in Germany until 1964.

${ }^{29}$ Grundschulen = primary or basic schools from grade 1 to grade 4; offering basic education to enable the pupils to attend a secondary school type. This school type exists in Germany since 1965.

${ }^{30}$ Hauptschulen = secondary general school from grade 5 to grade 9 or 10; provides its pupils with a basic general education to enable them to continue their education in an apprenticeship combined with the attendance at a vocational school or at a subsequent secondary school to receive a more expanded education.

${ }^{31}$ Realschulen, Mittelschulen = intermediate or middle schools from grade 4 to grade 10; provides its pupils with a more extensive general education and offer the possibility to attend higher vocational schools or to switch to a grammar school.

${ }^{32}$ Gymnasien = grammar schools, up to grade 12 or 13; provide an intensified general education and leads to the general entrance qualification for higher education.

${ }^{33}$ Gesamtschulen = comprehensive schools; this school type combines elements of secondary general schools, intermediate schools and grammar schools. 
state are available. Unfortunately, statistics on school size by number of classes, which would provide information about the number of parallel classes in schools and therefore on opportunities of differentiation, are not available via statistics on national level and therefore via this data compilation.

School attendance is compulsory in Germany but it is characterized by a very high extent of free choice between different school types. The time series on pupils offer information on the development of school attendance by school types. This information is provided the national level and on individual federal states level. In the case of the German school system the educational expansion is reflected in a strong shift of school attendance between the individual school types (Lundgreen, P.; Köhler, H., 2014, p. 57-62). Developmental differences between individual federal countries can also be analysed. The choice of pupils groups between school types can be seen in the context of different education opportunities. In the time series with the percentage of age cohorts by school types the development of educational participation can be analysed (participation rates of the age groups). Table 2.166 of this compilation in histat contains population in the age of 6 years, 13 years, and 18 years for the Federal Republic of Germany and for Germany after reunification. Pupils aged 13 years stand for pupil populations who attend all school types. Pupils aged 18 years, stand for pupil populations who attend the higher secondary level II to take the Abitur. Unfortunately, the population data are not disaggregated by gender, so that the pupil's age rate could not be differentiated by gender. Information on religious denomination and on social origin of the pupils are not available. The official statistics do not collect this information.

This data compilation enables to connect its information on school attendance with the period of the German Empire, as provided by the Data Handbook Volume II, Part $1^{34}$ and Part 2,, edited by Müller, Zymek and Herrmann. Differences in the regional territory should be carefully taken into account. Furthermore, due to the time period and the societal system of that period of the German Empire, the data contains mainly information on male pupils. The data compilation can be supplemented by Volume IX of the Data Handbook, "Schools and Universities in the German Democratic Republic, $1949-1989$ ", compiled by H. Köhler and Th. Rochow. In this case, two different educational systems can be compared, which existed in the same time period. The contents of Köhler's and Rochow's compilation will be discussed later in the text.

2.1.5 Vocational schools and higher education institutions in the Federal Republic of Germany (FRG) from 1949 to 2001

Furthermore, Peter Lundgreen dedicated himself in collaboration with Jana Scheunemann and Gudrun Schwibbe to the topic of vocational schools and higher education institutions. Volume VIII of the Data Handbook consists of two parts: Part 1 is on "Vocational Schools in the Federal Republic of Germany (FRG) 1949-2001", ${ }^{36}$ whereas Part 2 deals with "Higher education institutions in the Federal

\footnotetext{
34 "Social History and Statistics of the School System in the States of the German 'Reich', 1800-1945".

35 "Higher secondary Education for the male population in the Prussian state and in the Prussian Districts, 1832 to $1941 "$.

${ }^{36}$ Datafile: Lundgreen, Peter; Scheunemann, Jana (2008): Berufliche Schulen in der Bundesrepublik Deutschland 1949-2001. GESIS Datenarchiv, Köln. histat. ZA8201 Datenfile Version 1.0.0, doi:10.4232/1.8201. Publication: Lundgreen, Peter; Scheunemann, Jana; Schwibbe, Gudrun (2008): Datenhandbuch zur Deutschen
} 
Republic of Germany 1949-2001". ${ }^{37}$ A total of about 20,000 time series on vocational schools and higher education institutions have been acquired from information in the official statistics. In Volume VIII the development of these educational institutions are documented via numerous variables in a very differentiated manner. Four substantial points of focus were recorded statistically: (1) institutions - a precise history of all types of vocational schools and all types of universities; (2) participation - pupils or students in these institutions; (3) qualification - pupils or students according to the professional or academic subject of their education; and (4) graduates - type of qualification and success rates of the pupils/students. The data collection is rounded off with population data for the territory of the Federal Republic, which provides the age distribution of the population according to territory, nationality and sex.

In the following part 1 of the compilation is described more in detail. After that the focus is on the higher education (part 2 of the Data Handbook Volume VIII).

Vocational education and the entry into the professional world vary in different national systems. This is a result of long time historical development processes. In general, three qualification stiles can be distinguished. The German system is categorized as occupation-oriented. (see: Deissinger, Th. (1999), S. 189-208) ${ }^{38}$ The first part of the Data Handbook at hand aims to document the occupation oriented patterns of qualification statistically. Currently, there are about 350 training professions in Germany, which emerged from 700 training professions in the early post war period. The authors decided to categorize the training professions according to the classification of the official statistics. Therefore, they are classified in six vocational sectors which reflect statistically the vocational aims. ${ }^{39}$ Additionally, the official statistics documented in 1945 three vocational school types: I) vocational schools, ${ }^{40}$ II) full-time vocational schools (Berufsfachschulen), ${ }^{41}$ and III) professional or technical schools ('Fachschulen') ) $^{42}$ (Lundgreen, Peter; Scheunemann, Jana; Schwibbe, Gudrun (2008), p. 20). All further vocational school types have emerged later in the 1960s and in the 1980s. The distribution of the different vocational school-types' institutions across the German regions (Länder) is also reported in this compilation. The German cultural federalism leads to the fact that the individual German countries developed specific approaches, which resulted into an uneven distribution of education institutions. Commonalities and differences between the German countries in their offer

Bildungsgeschichte. Vol. VIII: Berufliche Schulen und Hochschulen in der Bundesrepublik Deutschland 19492001. Teil 1: Berufliche Schulen. Göttingen: Vandenhoeck \& Ruprecht.

${ }^{37}$ Datafile: Lundgreen, Peter; Schwibbe, Gudrun (2008): Hochschulen in der Bundesrepublik Deutschland 19492001. GESIS Datenarchiv, Köln. histat. ZA8202 Datenfile Version 1.0.0, doi:10.4232/1.8202. Publication: Lundgreen, Peter; Scheunemann, Jara; Schwibbe, Gudrun (2008): Datenhandbuch zur Deutschen Bildungsgeschichte. Vol. VIII: Berufliche Schulen und Hochschulen in der Bundesrepublik Deutschland 19492001. Teil 2: Hochschulen. Göttingen: Vandenhoeck \& Ruprecht.

${ }^{38}$ Deissinger, Thomas (1999): Beruflichkeit als Zusammenhang. In Zeitschrift für Pädagogik. 40. Beiheft. S. 189208.

39 I) professions involved in agriculture, animal agriculture, and forestry; II) miners, stone cutters; III) manufacturing occupations; IV) technical occupations; V) service occupations; VI) other work areas.

${ }^{40}$ Vocational schools enable a dual form of vocational training by combining training in the part time school and at the workplace.

${ }^{41}$ Full-time vocational schools or 'Berufsfachschulen' offer vocational preparation or a professional qualification as a state-certified technical/ business assistant.

${ }^{42}$ Professional or technical schools ('Fachschulen') are for pupils with completed vocational education, who want to get an advanced education (i.e. master schools, technical schools). In contrast to the vocational school the full-time vocational schools (Berufsfachschulen) and the professional or technical schools (Fachschulen) are statistical aggregates, that combine a wealth of distinct types of schools, partly with a long historical tradition. 
of vocational education opportunities can be analyzed. The main part of this data compilation consists in the use of the educational offer. Pupils are characterized according to specific features. Again, the information on the social origin is not available in the sources. Additionally, the religious destination could not be collected. In contrast, age, gender, nationality and educational background of the pupils could be documented for long periods. Furthermore, data on school leavers and their obtained qualifications are available. The official statistics offers information on professions so that the compilation contains detailed information on vocational sectors, and on occupational groups. Therefore, the pupils' population can be analyzed under the aspect of their educational goal.

While apprenticeship and vocational education leads to a well-defined profession, higher education or university education includes not always a clear occupational profile. However, the labor market for young academics is divided into three segments: academic life, the public service and the economy (Lundgreen, Peter; Scheunemann, Jana; Schwibbe, Gudrun (2008), p. 63). The official statistics distinguish between seven types of higher education institutions (= Hochschularten). ${ }^{43}$ Among these types universities of applied sciences (= Fachhochschulen), administration colleges (Verwaltungsfachhochschulen), and the comprehensive universities (Gesamthochschulen) are new, and which have only been added in the 1970s. All other types of higher education institutions reach back to the time of the $19^{\text {th }}$ century. In the past technical universities and universities have been listed separately by the official statistics. This separation was abolished by official statistics in 1972 . In the context of the current data compilation the authors carried on to collect technical universities and universities separately in order to establish the comparability to the other Data Handbooks dealing with higher education in the $19^{\text {th }}$ century and to monitor the development of the two segments after 1972 (Lundgreen, Peter; Scheunemann, Jana; Schwibbe, Gudrun (2008), p. 65).

In histat data on the number of universities by type of higher education institution and by German federal states (Länder) are available for the period from winter term 1949 until winter term 2001. The higher education institutions are subdivided into 10 categories. ${ }^{44}$ The data offer a statistical overview on the institutional history of the university system. The expansion of universities can be assessed by the number of students. In the official statistics students at universities are grouped according to disciplines or fields of study and not according to their later occupations. The authors follow this organizational principle in their data compilation. Thus, shifts in the offered range of universities' subjects as well as changes in the students' demand are recognized. The students' demand is an indicator of the collective assessment of labor market opportunities for the respective degrees (Lundgreen, Peter; Scheunemann, Jana; Schwibbe, Gudrun (2008), p.64). In histat time series

\footnotetext{
${ }^{43}$ The following terms were used for the German higher education system: The term 'higher education institutions' (= Hochschularten) is used as general term for all institutions offering higher education. There are three types of higher education institutions: First, universities (= Universitäten), technical universities (= technische Universitäten), and comprehensive universities (= Gesamthochschulen). They offer strong theoretical and academically-oriented degree programmes and a broad range of disciplines. Second, universities of applied sciences, or technical colleges (= Fachhochschulen), including administration colleges or universities of administration (= Verwaltungsfachhochschulen). Instructions at these institutions are more practice-oriented to prepare students for the requirements of professional life. Third, specialised institutions of higher education, such as colleges of art, film and music, colleges of education, theological colleges (= spezialisierte Hochschulen: Kunsthochschulen, Filmhochschulen, Musikhochschulen, pädagogische Hochschulen, theologische Hochschulen).

44 Universities (without technical universities); technical universities (= technische Hochschulen); comprehensive universities; colleges of education; theological colleges; art and music colleges, universities of applied sciences (= Fachhochschulen), one with and one without administration colleges; administration colleges; and finally the higher education institutions in general.
} 
on university entrants and students by type of higher education institution and by field of subject are also provided at the national level. Furthermore, the students' nationality, gender, and age has been gathered. Students can be analysed by their personal characteristics, their study success, and by the type of university. Here again, no information on social origin could be collected.

The authors compiled additionally time series of students for single higher education institutions on the level of the federal states. This has been done for individual institutions of universities, technical universities and comprehensive universities (Tables Tab. 2.1 to 2.11 in the Data Handbook). Unfortunately, these data are not in histat but can be ordered from the GESIS Data Archive free of charge. Finally, the age distribution of the population by nationality (i.e. German and Foreign), by gender, and by region (only West Germany and East Germany) is reported.

Potential uses and limitations of the data compilation: The Data Handbooks Volume VII on the general secondary schools in the Federal Republic of Germany (FRG) and Volume VIII on vocational and higher education in the FRG describe the German educational system since 1945. The educational system of the FRG built upon the structure of the German Empire's educational system. ${ }^{45}$ Therefore, the analysis of the educational system for a long time-span from the period of the German Empire to the period of the Federal Republic of Germany is possible. In this context, the authors formed categorizations of students by field of study, to enable comparisons with the two German periods $^{46}$ (Lundgreen, Peter; Scheunemann, Jana; Schwibbe, Gudrun (2008), p.155). The changes of the German borders as a result of the $2^{\text {nd }}$ World War and therefore the break in the time series should be taken into account. The data compilation on the educational system of the former German Democratic Republic (GDR), which will be presented in the following chapter, completes the statistical information. But here it is important to take into account the deep system break, which was made in the period of the Soviet occupation and the foundation of the GDR. The history of the foundation, differentiation and integration of various educational institutional types in the field of vocational training as well as of the higher education can be traced. Pupils and student flows indicate the use of these educational institutions and finally the educational expansion. Here again, sources of official statistics give no insight into the social origin and the religious denomination of the students. Other characteristics as age, gender, and nationality therefore can be used to describe and compare students and groups of students.

2.1.6 Schools and higher education institutions in the former German Democratic Republic, 1949 1989

Subsequently, Volume IX of the Data Handbook, "Schools and higher education institutions in the German Democratic Republic, 1949 - 1989"47, was published by Helmut Köhler and Thomas Rochow.

\footnotetext{
45 For example the three-tier school system, some institutions of the higher education as for examples universities, technical universities, teacher training colleges, etc., German country specific features.

${ }^{46}$ Theology was separated from the subject group of linguistics and cultural studies and is listed in this compilation as a data series on its own. Legal sciences are separated from economics and social sciences and reported as an independent subject. Veterinary medicine is not reported as an individual subject, but is added to the subject group medicine. However, under the subject group medicine, veterinary medicine is found as individual series.

47 Datafile: Köhler, Helmut; Rochow, Thomas (2014): Schulen und Hochschulen in der Deutschen Demokratischen Republik, 1949 - 1989. GESIS Datenarchiv, Köln. histat. ZA8381 Datenfile Version 1.0.0,
} 
The authors provide statistics for the entire educational system of the German Democratic Republic. For this purpose, the researchers accessed the previously unpublished data of GDR's educational statistics, some of which can only be found in archives. All of the compiled statistics begin first at the level of the GDR as a whole, followed by data for the individual German states ${ }^{48}$, and they then document the statistical development also at the GDRs' district level. The first section of the tables in the handbook concerns the general schools and the individual school types. Data on preschool education and nursery day care is presented in a second chapter. The third chapter is concerned with data on school and vocational education and training. Then, in the fourth section, the development of the colleges and universities is presented.

It is important to take into account that this Data Handbook differs from the structure of the other Data Handbooks. The reason for this is rooted in a deep political system change, caused by the fact that this part of Germany was the Soviet Occupation Zone (Sowjetische Besatzungszone, SBZ). The division of the general school system into lower and higher secondary schools with different school types was replaced by a uniform course of education, structured by school or educational levels. The new polytechnic secondary school (POS) was attended by all children until the $10^{\text {th }}$ class. After the completion of the $10^{\text {th }}$ class a vocational education or the visit of the extended comprehensive school (EOS) with the grades 11 and 12 was possible. The successful completion of the $12^{\text {th }}$ grade allowed to attend university. Vocational schools on the other hand offered the possibility to begin an apprenticeship or to attend the so-called Fachschulen, i.e. professional or technical schools. The completion of professional school training, in turn, allowed the attendance of a university. In fact, professional schools have undergone an upgrade within the educational system of the former GDR, which was a process of approximation to university standards. Therefore, universities and professional schools have been treated jointly by the authors. It is important to note that professional schools of the German Federal Republic cannot be compared unreserved with professional schools of the former GDR. Finally, the unified education system was supported by special schools on the one hand and by schools for highly gifted talents on the other hand.

The data are also available at different regional levels. First, information on the various educational segments is included at the GDR's national level. Second, the district-level of the GDR is provided. ${ }^{49}$ Then, the authors linked key data on the German Länder which existed until $1951^{50}$ with data of the GDR's district level. In this way, they constructed long time series at the German regional level from 1945 to 1989 and allow to connect their data to the Data Handbooks dealing with data prior to 1945 and after $3^{\text {rd }}$ October 1990. This part involves time series on schools, pupils, full-time teachers, Kindergartens and children in care, after-school care centres and day schools, vocational schools, technical colleges, universities and students.

doi:10.4232/1.12139.

Publication: Köhler, Helmut; Rochow, Thomas (2008): Datenhandbuch zur Deutschen Bildungsgeschichte. Vol. IX: Schulen und Hochschulen in der Deutschen Demokratischen Republik 1949-1989. Göttingen: Vandenhoeck \& Ruprecht.

${ }^{48}$ The offer of the data on German states level is a special contribution of the authors which facilitates the construction of long time-series. In the context of the administrative reform of 1951 the five German countries on the GDR-territory (Brandenburg, Mecklenburg, Saxony-Anhalt, Saxony, and Thuringia) had been replaced by 14 administration districts (Bezirke), which divided further in rural and urban counties (Land- und Stadtkreise).

${ }^{49}$ Berlin, Dresden, Rostock, Schwerin, New-Brandenburg, etc.

${ }^{50}$ Brandenburg, Mecklenburg, Saxony, Saxony-Anhalt, Thuringia. 
Finally, the following two points should be mentioned briefly. First, the data compilation contains statistical information on the educational success. In other words, the data on relative school attendance for the class level 11 indicates the part of pupils who successfully changed to the higher extended comprehensive school. The rate of repeaters, the transferring rate into special schools, and data on final examinations gives additional information about success and failure. In the context of higher education, time series on university graduates and on finished doctorates as well as the rate of premature withdrawal are available. Second, the data compilation does unfortunately not include the age structure of university and professional school students. In order to calculate the entrance rate of students, admitted full-time students can be related to the average population of the age groups. Data on population by age groups until the age of 30 years are also included.

Potential uses and limitations of the data compilation: The data can be connected to other data in histat to construct long time series. The statistics on the GDR-educational system of this publication go beyond the official, published statistics of the former GDR. However, the Data Handbook on the former GDR education system differs in its structure and meaning from the other Data Handbooks on German educational history, caused by the radical brake with central characteristics of the traditional German Educational System after the foundation of the GDR. Furthermore, a standardization of school careers took place. Quotas of repeaters and of drop outs stagnated at a low level and the quota of high school graduates did not change significantly. ${ }^{51}$ This should be taken into account when long time series are reconstructed.

\subsubsection{The staff of the higher education institutions in the Federal Republic of Germany 1953-2005}

Volume X of the Data Handbook was published by Peter Lundgreen, Gudrun Schwibbe and Juergen Schallmann which deals with "The staff of the higher education institutions in the Federal Republic of Germany 1953-2005"52. The personnel in the higher education institutions are described statistically in numerous time series on the five large topics: (1) personnel according to personnel groups - fulltime scientific personnel, non-scientific personnel; (2) professors and research assistants according to subject group; (3) professors and research assistants according to age group; (4) number of newlyqualified lecturers annually; (5) research assistants according to their employment relationship and the type of funding.

The authors compiled the data mainly on the basis of the official statistics, which have been enlarged by publications of the Science Council (Wissenschaftsrat), the HIS-Hochschul-Informations-System $\mathrm{GmbH}$ (Higher education institutions Information System), and the Federal Ministry of Education and Research. They included the division between full-time and part-time personnel. Due to different

\footnotetext{
${ }^{51}$ A. Huschner pointed out that in 1970 the quotas of pupils who graduated at high school had been at the same level in the former German Democratic Republic (GDR) and in the Federal Republic of Germany (FRG). Then, until the end of the 1980s the former GDR had frozen the quota of high school graduates at the level of $12 \%$ to $14 \%$ of the respective age cohorts. This was contrasted with a rising proportion of high school graduates in the FRG in the same period to over 30\%. (Huschner, Anke (2001): p.819)

52 Datafile: Lundgreen, Peter; Schwibbe, Gudrun; Schallmann, Jürgen (2010): Das Personal an den Hochschulen in der Bundesrepublik Deutschland 1953-2005. GESIS Datenarchiv, Köln. histat. ZA8380 Datenfile Version 1.0.0, doi:10.4232/1.8380.

Publication: Lundgreen, Peter, with Gudrun Schwibbe and Jürgen Schallmann (2009): Datenhandbuch zur Deutschen Bildungsgeschichte. Vol. X: Das Personal an den Hochschulen in der Bundesrepublik Deutschland 1953-2005. Göttingen: Vandenhoeck \& Ruprecht.
} 
statistical reporting of personnel figures, long time series have been compiled for higher education institutions in general, universities, and universities of applied sciences, and not for a finer division of the higher education institutions (Lundgreen, P. with G. Schwibbe and J. Schallmann, (2009), p. 29). The authors started from the present categorical scheme and adapted the data of the older statistical publications to this scheme. For the statistical presentation the authors began with large groups. Then, statistics were compiled on medium-sized subgroups. Finally, they gathered time series on personnel- and functional groups. The classification of the data is as follows: 1. Scientific or nonscientific staff; 2. Scientific staff: full-time and part-time; 3. Full-time scientific staff: individual subgroups; 4. Salary grades and functional groups within the individual subgroups (Lundgreen, P. with G. Schwibbe and J. Schallmann, (2009), p. 29). Functional groups are also referred to as official titles (Dienstbezeichnungen) or as staff group by the authors. Functional groups of non-scientific personnel are administrative staff, library staff, technical staff, care staff of medical universities, and workmen. Functional groups of scientific staff are in the case of part-time scientific staff: honorary professor, private lecturer, assistant lecturers, and tutors. In the case of full-time scientific staff functional groups are: scientific assistants (= Assistent), research assistants (= wissenschaftlicher Mitarbeiter), Academic Councillors (akademischer Rat), and professors.

In histat information on the staff is provided in combination with, for example, the employment relationship, gender and age, the type of higher education institution, the study area, the salary grades, or the type of financing.

Finally, the yearly amount of habilitated academics is presented by study area, by gender, and by age.

Potential uses and limitations of the data compilation: The period of the Federal Republic of Germany has witnessed an important higher educational expansion. Thus, an expansion of the higher education capacities became necessary, especially the extension of scientific staff. A central aim of the authors therefore was the possibility to link their data with other Data Handbooks to retrace a long period of the higher education development until to the present or to compare the development of different educational segments in the period of the Federal Republic of Germany. Under this aspect, the Data Handbook Volume VIII ${ }^{53}$ with its detailed information on students contains possibilities of useful additions and a content related interlinking according to subject classification and quantity relationships between university students and instructors. The aim of the data compilation of the Volume $\mathrm{X}$ is to understand and to analyse the change of the higher education institutions during the period of analysis (1953 to 2005) by means of the personnel statistics. The development of the individual staff groups can be analysed and can be compared with each other staff group and between individual scientific areas. Structures of scientific personnel staff can be described in terms of salary grades or full- and part-time employment. The development of the proportion of women can be described according to various characteristics as for example staff group, salary grades, etc. Furthermore, it is possible to analyse gender equality between subject groups and individual subjects.

However, there have been problems to compile consistent time series. The main occupational scientific staff categories changed over the period of 50 years because of reforms of the staff structure (e.g. due to the Framework Act for Higher Education (HRG)), the implementation of new

\footnotetext{
${ }^{53}$ Vocational Schools and Universities in the Federal Republic of Germany 1949 to 2001.
} 
salary grades and changing systems of categories of the official statistics. Some problems should be addressed in the following: Since 1980 official statistics report the scientific staff additionally according to salary grades and since 1988 the full-time scientific staff is categorized into four subgroups: professors, lecturers and assistants, scientific or artistic employee, teachers for special tasks. (Lundgreen, P. with G. Schwibbe and J. Schallmann, (2009), p. 144) The authors grouped the statistical information on staff groups for the period from 1953 to 1979 according to the statistical categorization of 1988. For this reason, they compiled consistent time series and made the data compatible to the time series from $1980 / 88$ to 2005 . However, there are breaks in the time series for the time spans of $1966 / 72$ and $1979 / 80$.

Furthermore, the variable 'academic staff' must be mentioned here more precisely. In official statistics the term 'academic staff' is not in use. Until 1987 the official statistics recorded the staff according to functional groups (i.e. official titles (Dienstbezeichnungen)). Since 1988 two upper groups are introduced: 1) lecturers and assistants, 2) academic and artistic employees (Lundgreen, P. with G. Schwibbe and J. Schallmann, (2009), p. 44). Here again, the authors regrouped the statistics from 1953 to 1987 in order to build consistent time series. The time series on academic staff show jumps in the values. Therefore, the authors suggest to use the sum of all functional groups (i.e. the academic staff in general). Nevertheless, the internal differentiation should be taken into account for the analysis of scientific universities. In this way, structural shifts in the occupational employment system become apparent (Lundgreen et al., (2009), p. 44). The official statistics distinguish since 1972 among three hierarchical levels of scientific disciplines: first, subject groups (i.e. natural sciences, etc.), second, research area (i.e. chemistry, etc.), and third, subject speciality (i.e. physical chemistry, etc.). In Data Handbook VIII on students of higher education the students are categorised only for the two first levels 'subject groups' and 'research area'. In the official statistics the personnel groups have also been categorised for the two levels. Therefore, the data compilations of the Data Handbook VIII on students and of the Data Handbook X on scientific staff correspond in this respect. But there are small variations in the way the subject groups have been created between the data compilation of volume VIII on students and the data compilation of volume $\mathrm{X}$ on the personnel of higher education institutions. For the compilation on personnel, the authors adapted the subject categories of the period from 1972 to 1979 to the statistical classification of 1980. Therefore, theology was added to the group of linguistics and cultural studies. In the case of the statistics on students of higher education institutions (i.e. Data Handbook VIII) theology is reported separately to enable comparisons with the period of the German Empire. In the case of personnel legal sciences was added to the group of economic and social sciences. In contrast, students of legal sciences are reported separately. (Lundgreen, P. et al. (2009), p. 159 and Lundgreen, P. et al. (2008), p. 155)

\subsubsection{Teachers at Schools in the Federal Republic of Germany 1949 to 2009}

Finally, in the publication "Teachers at Schools in the Federal Republic of Germany 1949 to 2009"54, which is Volume XI of the Data Handbook, Peter Lundgreen and Jürgen Schallmann documented long

\footnotetext{
54 Datafile: Lundgreen, Peter; Schallmann, Jürgen (2013): Die Lehrer an den Schulen in der Bundesrepublik Deutschland 1949 bis 2009. GESIS Datenarchiv, Köln. histat. ZA8550 Datenfile Version 1.0.0, doi:10.4232/1.12379.

Publication: Lundgreen, Peter; Schallmann, Jürgen (2013): Datenhandbuch zur Deutschen Bildungsgeschichte.
} 
series on the numbers of teachers in the schools of the Federal Republic of Germany. The following information is available in the Handbook: the number of teachers is divided statistically according to school type, scope of employment, teaching professions ${ }^{55}$, age, and entries to and departures from the teacher stock. Additionally, statistical information on student teachers is provided. Finally, information was gathered on unemployment (according to sex, teaching post, duration and age).

In the case of the general school system, educational expansion means that there is a shift between the segments. In other words, the pupils remain longer in the general school system, whereby the share of Grammar school pupils increased and the one of pupils in general secondary schools (= Hauptschulen) decreased. At the same time, the number of teachers tripled between 1950 and 2010. Educational extension goes in hand with quality improvement, and the improvement of the teacherpupils ratio (Lundgreen, P. and Schallmann, J. (2013), p. 15). Furthermore, the school system as occupational field for teachers is a very complex, highly differentiated field. (Lundgreen, P. and Schallmann, J. (2013), p. 34) The yearly official statistics on institutional differentiation of school types have been summarized by the authors with the aim to get consistent time series on school types. The categorizations on general education school types and vocational school types have been the basis for these time series. Qualification, the acquisition of the teaching licence, and the employment in the school system are central variables that describe the young teacher trainees and the employed teachers as well as the growth and structure of employed teachers over time.

The large variety of school types ${ }^{56}$ is contrasted by only 7 teaching professions with long historical traditions. (Lundgreen, Schallmann (2013), p. 34) The authors aimed to combine these two characteristics, i.e. the distribution of teachers by their qualification and by their school type (i.e. the occupational field). Thus, in histat detailed time series are provided on teachers by age and gender for the German federal states and for Germany in general. ${ }^{57}$ They are additionally differentiated by their qualification ${ }^{58}$, by the type of school, and by their field of occupation. The school types are listed in a very differentiated way, starting with the pre-school institution and containing the different types of general education and vocational schools. ${ }^{59}$ Additionally, the employment relationship is reported. ${ }^{60}$ Finally, entrants and exits of the teacher stock are reported by type of

Vol. XI: Die Lehrer an den Schulen in der Bundesrepublik Deutschland 1949-2009. Göttingen: Vandenhoeck \& Ruprecht.

${ }^{55}$ Teaching professions in general schools and in vocational schools, disaggregated by gender and federal state

${ }^{56}$ The official statistics distinguishes between 15 general educational school types and 12 vocational school types.

${ }^{57}$ The data are available for individual federal states, the territory of the former Federal Republic of Germany, the territory of the new Länder until 1990, and finally the territory of Germany after reunification on $3^{\text {rd }}$ October 1990.

${ }^{58}$ i.e. Lehramt or the teaching profession

59 The categorical scheme on school types of the official statistics changed several times. The categorical system of 1997 then is the basis for the subdivision of the datacompilation of Lundgreen et al. This subdivision contains small variations between single federal states. This fact comes into effect in the case of data selection via histat. Here, first the regional level should be selected, then in a second phase the school type can be chosen.

${ }^{60}$ This means, the teacher staff is further categorized by information on employment situation. Under the term employment situation the official statistics distinguish between official and extra-official employed teachers (Lundgreen, Schallmann (2013), p. 78 and 165, appendix 3). 
school, individual federal states, and by gender. ${ }^{61}$ Reasons and structures of entries and exits can be described and compared in general and by school types as well as by gender.

However, statistical information on student teachers as well as information on unemployment (according to gender, teaching post, duration and age) is not offered in histat. These statistics can be ordered from the GESIS-Data archive. Information on university students, enrolled for the teacher training, is also available in the compilation of Data Handbook VIII ${ }^{62}$ (see above in the text).

Potential uses and limitations of the data compilation: This data compilation allows to analyze the development of schools in terms of the teacher staff. The long term development of employment relationships, mobility, and career perspectives can be analyzed. However, there are only limited possibilities to link these data to time series data prior to the period of the Federal Republic of Germany is limited. The reason for this is to be found in the professionalization history of the teaching profession. The typical differentiation into a lower and a higher school sector in the $19^{\text {th }}$ century German school system was associated with a separate education of teachers. While teachers of the lower school sector (i. e. the elementary school = Volksschule) were educated in seminars and obtained non-academic training, teachers of the higher school system ${ }^{63}$ followed an academic education at university. Moreover, teachers of the lower school sector were taught in all school subjects of the elementary school. They gained a kind of encyclopedic knowledge and they were expected to teach all subjects. The second stage of their education was a one-year practical training at school. In the period of the Weimar Republic, the seminar focused teacher training ceased and the training was located in pedagogical teacher training colleges (pädagogische Hochschulen). The training of teachers for the elementary school underwent a process of academization until the 1960s and finally there it was aligned with the teachers' education of the higher school sector (Lundgreen (2011), p. 16ff.).

Teachers of the higher school sector had to pass the teachers education examination, which was an academic university education implemented in 1810 at the philosophy faculty. This examination covered at that time the subjects of philology, ${ }^{64}$ history, and mathematics. Due to the grammar curriculum, which included an increasing number of subjects, the academic teacher education increasingly became subject oriented. Since 1833 , teacher students studied the subjects at university which they will teach later and they became specialized subject teachers. However, they finished their university study with an examination in the specific subjects they had studied. Only in a second phase, they attended a practical period as teaching profession candidates (Lundgreen (2011, p. 11ff.). The academic subjects pedagogy and educational sciences have not been leading subjects for the pedagogical professionalization process, neither for teachers of the lower school sector nor for teachers of the higher school sector (see Lundgreen, 2011). Therefore, teaching students cannot be identified for the period of the German Empire.

\footnotetext{
${ }^{61}$ The following types of entrants are reported: newcomers, relocations (the same school type, but in another federal state), job change between school types, re-entry, and other reasons. Types of exits are: retirement, invalidity, relocations, job change, temporary contract, family reasons, and other reasons.

${ }^{62}$ Lundgreen et al.: Vocational Schools and higher education institutions in the Federal Republic of Germany 1949 to 2001

${ }^{63}$ Institutions of the so called Gymnasiale and Realgymnasiale Anstalten, which are the Grammar schools of today.

${ }^{64}$ Mainly the classical languages latin and classical greek, additional German, sometimes modern languages.
} 
Moreover, the Data Handbook Volume II of D.K. Müller and B. Zymek, Part $1^{65}$ offers time series on teacher seminars and the participants of teacher seminars. These time series contain the development of education institutions and their students for the lower school sector. The Data Handbook, Volume I, on higher academic studies in Prussia and Germany, 1820 - 1944, published by Titze et al., also contains long time series on students by subjects and faculties under the table header 'Subjects/Faculies'. As mentioned above, not only teacher students enrolled in subjects of the philosophic faculty, as for example philology and history. Furthermore, a part of students who are enrolled in subjects of natural sciences or mathematics are teacher students. Additionally, the study of pedagogy is not associated with the education of teachers for the higher school sector. Therefore, teacher students cannot be identified by the field of subject. Yet it is possible to differentiate among various institutions of higher education, among others 'pedagogic academies' (Pädagogische Akademien). Pedagogic academies are the Prussian precursors of pedagogical teacher training colleges (pädagogische Hochschulen) and therefore education facilities for teachers of the lower school sector.

Finally, there is the Data Handbook Volume VI, published by V. Müller-Benedict, on academic careers in Prussia and Germany between 1850 and 1945. This data compilation contains several time series on teacher staff of the higher school sector in Prussia. Tables are offered on the stock of teachers, disaggregated by the type of teacher (for example: school director, schoolmaster (=Oberschullehrer), student teachers (i.e. Referendare), etc.); by the age structure in years; etc. In summary, information on young teacher students for the period of the German Empire is available only for teacher students of the lower school sector. Information on teacher staff for the period of the German Empire is available for teachers of the higher school sector. The data compilation of Lundgreen on teachers in the Federal Republic of Germany can also be complemented by Köhlers data compilation on Schools and higher education institutions in the German Democratic Republic. In this case, the differences of school systems and of the educational policy should be taken into account.

\subsection{Data compilation in the context of individual research projects}

\subsubsection{Education, state funding, and economic growth}

2.2.1.1 Claude Diebolt: public educational expenditure, educational participation, and economic growth

Another approach to the subject of education development originates from the field of quantitative historical economic research. A long tradition exists in recording and predicting the temporal evolution of economic growth as precisely as possible with the help of elaborate statistical methods. Against this background, research on the relationship between education and economic growth should also be mentioned here. The scientific controversy as to whether the educational level is a cause or a consequence of economic development provided the impulse for the comprehensive Data Handbook "The long-term development of the German school system in the 19th and 20th century $^{\prime \prime 6}$, published by Claude Diebolt. In this data handbook he constructed more than 900 long

\footnotetext{
65 "Social History and Statistics of the School System in the States of the German 'Reich', 1800-1945"

${ }^{66}$ Datafile : Diebolt, Claude (2005): Die langfristige Entwicklung des Schulsystems in Deutschland im 19. und 20. Jahrhundert. GESIS Datenarchiv, Köln. histat. ZA8221 Datenfile Version 1.0.0, doi:10.4232/1.8221.
} 
time series from 1775 to 1989 on the development of the German educational system, reported for the German Empire in general, for Prussia, for the Prussian states, and the capital city Berlin. It is a detailed compilation of the different levels of the educational system ${ }^{67}$, the German economy ${ }^{68}$ and the population of the German Empire and of the Prussian states by gender as well as the Prussian population by age groups and by gender. Furthermore, Berlin occupies a special position, because it is the capital city of Germany. Berlin played a leading role in the economy, culture, and societal developments. Therefore, the author created detailed time series for the capital city. This information on Berlin is available until 1943 in this compilation. ${ }^{69,70}$ This data compilation is intended as an instrument for historical research and thus in respect to its concept it is similar to the concept of the "Data Handbooks on Historical Education Research", as discussed above. The added value is the additional and detailed collection of economic time series.

A key goal was to form continuous time series. However, complete statistics for the period of examination become ever rarer, the more they extend back into the time periods prior to the foundation of the German Empire, or where they reach time periods that are marked by upheavals and revolutions. The author closed gaps in the time series based on his own calculations. Furthermore, with this data handbook he has created a database that allows the empirical examination of the relationship between investments in the educational system and the formation of human capital.

In several follow-up studies, Diebolt compiled additional time series on public expenditure on education for international comparisons. ${ }^{71}$ The GESIS-Archive studies $Z A 8174^{72}$ and $Z A 8143^{73}$ provide

Publication : Diebolt, Claude (1997): L'évolution de longue période du système éducatif allemand: 19e et 20e siècles. Cahiers de l'ISMÉA. Économies et Sociétés. Série: Histoire quantitative de l'économie française. A.F. No. 23, 1997.

${ }^{67}$ Information on institutions of and pupils or students in preschools, community schools, higher schools and universities

68 Information on national income, education expenditure in general and in the case of Prussia further disaggregation has been made by educational institutions and by expenditure areas, wholesale and retail prices, costs of living

${ }^{69}$ Information are about the number of school-age children; pupils by school types; number of successful school-leavers of grammar schools; Berlins educational expanses on elementary schools and on higher education; Berlins net expenditure on the construction of new school buildings; Berlins gross receipts and expenditures in general; Berlins gross receipts and expenditures for education in general, by school types, and per head of pupils; Berlins children by age-groups, and Berlins population by gender

70 See additionally the study on "Expenditures on Education in Berlin between 1829 and 1914" histat: Datafile: Diebolt, Claude (2004): Bildungsausgaben für Berlin 1829-1914. GESIS Datenarchiv, Köln. histat. ZA8178 Datenfile Version 1.0.0, doi:10.4232/1.8178.

Publication : Diebolt, Claude: L'Évolution de Longue Période du Système Éducatif Allemand XIX et XX Siècles. Économies et Sociétés. Février-Mars 1997, p. 298-333.

${ }^{71}$ See the following publications:

Diebolt, C., 1997: L'évolution de longue période du système éducatif allemand: 19ème et 20ème siècles, in: Numéro spécial de la revue Economies et Sociétés, 23, S. 1-370, Série AF.

Carpentier, V.; Diebolt, C.: "Public Expenditure on Higher Education in Germany and the United Kingdom after World War II", in: Historical Social Research. Vol. 24, n¹, 1999, pp. 187-196.

Diebolt, C., 1995: Les indicateurs physiques du volume de l'éducation en France, in: Education et croissance économique: évolution de longue période et prospective. Union Européenne, Vol. 1. Carry, A./Diebolt, C.et al., September 1995, 4 vols., 1482 pages.

Diebolt, C., 1999: Government Expenditure on Education and Economic Cycles in the Nineteenth Centuries. The Case of Spain with Special Reference to France and Germany, in: Historical Social Research, Bd. 24, Nr. 1, S. 331. 
Diebolt's time series for five countries on public educational expenditure. ${ }^{74,75}$ Education statistics differ significantly between countries. Therefore, the author systemized different nomenclatures and definitions of national educational statistics. On the basis of this systematization he designed comparable data series. The general public expenditure on education in current and in constant prices is available in study ZA8174 from 1829 to 1989 for Germany, France, Great Britain, and Spain. For France and Germany, the gross domestic product, population, and the number of pupils in general is additional available via the study ZA8143.

For Japan and Spain, detailed information on the state budget is given in the study ZA8174. In the case of Japan the expenditure on education is reported for the state, for the Japanese prefectures, and for towns and large cities. This information is complemented by time series on Japanese gross national product, national income, the Japanese expenditure on military and states expenditure, national debt, and public investments. A price index based on 1934-1936, and finally the population in thousands is also available.

In the case of Spain the educational expenditures are differentiated by the type of educational institution and they are reported for the Spanish state in general. Additionally information is included on the state expenditures in general and on the national income. The time series are completed with series on a price index based on 1958, and finally the population in thousands is reported. All information is given in constant and in current prices.

Potential uses and limitations of the data compilation: As mentioned above, the different levels of detail of the time series for France, and Great Britain on the one hand and for Spain and Japan on the other hand is because the author collected the series in the context of different individual studies. However, Spain's and Japan's educational expenditures can be compared with the expenditures of Germany, France, and Great Britain on the level of the general states expenditures. As already indicated, via the Data Handbook on the long term development of the German school system Diebolt collected detailed information on Prussian and German educational expenditures. This time series, which are disaggregated by educational institution, might offer opportunities for comparison with Spain.

In the context of international comparisons on educational expenditures it is necessary to develop common statistical concepts. National statistics on education and on national accounts contain major

Diebolt, C., 2000a: Dépenses d'éducation et cycles économiques en Espagne auX XIX e et XX e siècles. In: Collection Logiques Economiques dirigée par Gérard Duthil, édition L'Harmattan, Paris, S. 105-136.

Diebolt, C., 2003: Accounting Expenditures on Education. Japan from Meiji Restoration to the Second World War. In: Historical Social Research, Vol. 28, No. 1/2, pp. 290-305.

72 "Education Spending in Germany, France, Great Britain, Spain, and Japan, 1815-1989"

73 "Public Educational Spending between 1820 and 1996: Germany and France in Comparison"

${ }^{74}$ Datafile: Diebolt, Claude (2003): Bildungsausgaben in Deutschland, Frankreich, Großbritannien, Spanien und Japan von 1815 bis 1989. GESIS Datenarchiv, Köln. histat. ZA8174 Datenfile Version 1.0.0, doi:10.4232/1.8174.

Publication: Diebolt, Claude (2000): „Die Erfassung der Bildungsinvestitionen im 19. und 20. Jahrhundert. Deutschland, Frankreich, Großbritannien und Spanien im Vergleich“. In: Zeitschrift für Erziehungswissenschaft, Vol. 3, No. 4, p. 517-538.

${ }^{75}$ Datafile: Diebolt, Claude; Guiraud, Vivien (2000): Öffentliche Bildungsausgaben 1820 bis 1996: Deutschland und Frankreich im Vergleich. GESIS Datenarchiv, Köln. histat. ZA8143 Datenfile Version 1.0.0, doi:10.4232/1.8143.

Publication: Diebolt, Claude; Guiraud, Vivien (2000): Long Memory Time Series and Fractional Integration. A Cliometric Contribution to French and German Economic and Social History, in: Historical Social Research / Historische Sozialforschung (HSR), Vol. 15, No. 3/4, S. 4-22. 
differences. Additionally, especially the national statistics on education show breaks caused by changed statistical definitions and changing institutional developments. ${ }^{76}$ The author Claude Diebolt harmonized different national statistics by developing common definitions and common statistical groups. In order to obtain the value of national educational expenses, the reported respective prices have been deflated by using appropriate price indices, in order to get constant prices. In the case of Germany, France, Great Britain, and Spain, Diebolt referred to the wholesale price index and the cost of living index. A new index was also computed, to which was added the wholesale price index to one third and the index of living cost to two third (Diebolt, 2000: p. 524). Concerning the level of expenditure the development of other quantities as reference point is of importance. Possible reference points are the size of the population, the number of pupils, and the national product. Yearly growth rates are also interesting (Diebolt, 2000: p. 525). Diebolt provides harmonized time series on population, pupils, and national budgets which facilitate the calculation of relations as, for example, educational expenditures per head of the population, per pupil, or the share of educational expenditures in the national product on international comparison.

\subsubsection{Frank R. Pfetsch: Official science funding, scientific knowledge, and economic growth}

In the context of his study "The Development of Germany's science policy until 1914" Pfetsch collected data from 1850 to 1914 on the relationship of state funding, scientific knowledge, and economic growth. The territory under investigation is the German Empire and the five largest German countries Prussia, Bavaria, Saxony, Wuerttemberg, and Baden. The compilation contains time series on three topics: first, on state scientific funding and on scientific and economic growth; second, on scientific organizations and on published physiological journals in Germany, France, England and USA; third, on the development of a scientific organization (Association of German Natural Scientists and Doctors, abbreviation $G D N \ddot{A}^{78}$ ), in particular on the development of the sections and the attendance on GDNÄ-meetings.

Science is seen by the author as a social system of thought and of action. It is embedded in different fields of interests, which are the states interests, the interests of the society, and the economic interests. Within this context, Pfetsch tries to understand scientific action. (Pfetsch 1974: p. 16) Pfetsch defines science as the sum of all activities focused on expanding of knowledge. (Pfetsch 1974: p. 29) Science policy is defined as the sum of all measures aimed at academic teaching and research in institutions of higher education as for examples universities, as well as on extramural scientific institutions and research institutions of the economy. (Pfetsch 1974: p. 30)

In line with this theoretical concept the researcher accessed quantitative information on the interconnected activities and on the structure of the network of science, state, and economy. First, he collected the scientific organisations, established between 1750 and 1914 . Second, the author devoted special attention to the development of the association GDNÄ. ${ }^{79}$ Third, Pfetsch collected

\footnotetext{
${ }^{76}$ For example: closure of elementary schools (Volksschulen), and therefore implementation of primary schools (Grundschulen) and general secondary schools (Hauptschulen) in the Federal Republic of Germany.

${ }^{77}$ Datafile: Pfetsch, Frank R. (2011): Entwicklung der Wissenschaftspolitik in Deutschland bis 1914. GESIS Datenarchiv, Köln. histat. ZA8472 Datenfile Version 1.0.0, doi:10.4232/1.10410.

Publication: Pfetsch, F.R. (1974): Zur Entwicklung der Wissenschaftspolitik in Deutschland 1750 - 1914. Berlin: Duncker \& Humblot.

78 "Gesellschaft Deutscher Naturforscher und Ärzte"

79 In histat the following quantitative collected data are available: Yearly information is offered on the development of the number of sections in general, on the developments of the new formations of natural
} 
public expenditures on scientific projects by the German Empire and by the five largest German states. In this context he identified all scientific institutions which have been funded by the state and the private sector (except the industrial research institutions). The official expenses are itemised according to 1 ) the financing authority ${ }^{80}$,2) the scientific institutions (universities, etc.), 3) the orientation by scientific disciplines ${ }^{81}$, and 4) the orientation by economic, military, and general purposes. (Pfetsch 1974: p. 46) Finally, indicators on economic development have been gathered. ${ }^{82}$

Additionally, Frank R. Pfetsch compiled a further comprehensive "Data Handbook on Scientific Development: Government funding of science in Germany from 1850 to $1975^{\prime \prime 83}$ which is closely related to his publication "Development of Scientific Policy in Germany". In his data handbook, Pfetsch published statistical time series for the years from 1850 to 1975 on Germany's state expenditure on universities, on extramural research institutes, and on scientific projects from 1850 to 1914. The topic of Pfetsch's work therefore is the official science funding. The data collection relied again on the budgets of the largest German states Prussia, Bavaria, Saxony, Wuerttemberg, and Baden, and of the Empire in general. Additionally, these long statistical time series have been extended until the 1970s for the Federal Republic of Germany.

In general, the Data Handbook offers a selection of possible input-indicators for the development of science. Until the Second World War the Empire's development activities are reported as completely as possible and the activities of the German regions are reported partly, because only the five largest regions have been considered. Until the Second World War the researcher calculated the official expenditure on scientific development per year. Subsequently, the reports have been conducted in a 5 -year-period. This fact implies that short-term expenditure items might not have been collected.

The following characteristics of the employed official sources have affected the data collection: Official budget data reflect the administrations perspective and they are adapted to the information needs of the administration. This fact causes different categorization schemes between the German regions, because for the educational authorities the constitutional point of view has been decisive, whereas the material purposes by institutions and aims have been subordinated. Therefore, for example, expenditures on institutions of research societies may be listed in the budgets of some German regions for each individual research society (i.e. the Max-Planck-Research Society, Frauenhofer Society, etc.) and in the case of other German regions as compound item (i.e.: expenses on scientific research organisations). Another example is the budget issue 'institutions of higher education' (= Hochschulen), which is a large aggregate without differentiation of the individual

science association in connection with GDNÄ in general, on the development of participants in GDNÄconferences, and finally on the development of the average attendance in GDNÄ-section meetings. Pfetsch wanted to describe how scientific communities in the $19^{\text {th }}$ century have organized themselves. The development of the number of sections and the foundation of further natural science associations reflects the ongoing process of scientific specialisation and differentiation. (Pfetsch 1974, p. 271)

${ }^{80}$ Individual German states and German Empire in general

${ }^{81}$ Agriculture, natural sciences, etc.

${ }^{82}$ National income per head; employees of industrial sector; urban population; population by religious denomination

${ }^{83}$ Datafile: Pfetsch, Frank R. (2010): Datenhandbuch zur Wissenschaftsentwicklung; Staatliche Finanzierung der Wissenschaft in Deutschland 1850 - 1975. GESIS Datenarchiv, Köln. histat. ZA8051 Datenfile Version 2.0.0, doi:10.4232/1.10145.

Publication: Pfetsch, Frank R. (1985): Datenhandbuch zur Wissenschaftsentwicklung. Die staatliche Finanzierung der Wissenschaft in Deutschland 1850 - 1975. 2nd edition, Köln: Zentrum für historische Sozialforschung e.V. 
activities even if the higher education institutions are disaggregated by individual institutions. Furthermore, the itemisation of the large aggregates as for example the higher education institutions, the Max-Planck-research society, or the German Research Foundation by disciplines, objectives, detailed scientific activities and functions is not possible.

Potential uses and limitations of the data compilation: The Data Handbook's strength is the offer of all scientific relevant budget items as long term development. The collected budget items have been categorized by official departments, institutions of research and higher education (e.g. universities, scientific academies, ministries and authorities, etc.), functional areas (e.g. research and development, education and teaching, etc.), disciplines (natural sciences, social sciences, etc.), scientific activities (basic research, applied research, etc.), aims or research, and national and international projects. Furthermore, the official expenditures on science can be analysed at different levels of aggregation (see Pfetsch, 1985: p. 5-7). In the histat database selected time-series of the data handbook are available for download. The complete data handbook consists of 16 SPSS-files which can be ordered from GESIS Data Archive or be downloaded from the GESIS Archives' Data Catalogue (search online for doi:10.4232/1.10145).

2.2.1.3 Sascha O. Becker, Francesco Cinnirella, Erik Hornung, and Ludger Woessmann: Prussian census data as a source for the analysis of demographic and educational developments

Finally, the ifo database on Prussian economic history (abbreviation iPEHD) ${ }^{84}$ created by Sascha $\mathrm{O}$. Becker, Francesco Cinnirella, Erik Hornung, and Ludger Woessmann, contains a comprehensive summary of variables at district level in Prussia for the nineteenth century. These data come from the printed publications of the Royal Statistical Office of Prussia. The data of numerous censuses were conducted for the period from 1816 to 1901. These data provide a unique information source for micro-regional empirical research into economic history, in order to analyse the significance of education, religion, fertility and many other influencing factors ${ }^{85}$ on the economic development of Prussia in the $19^{\text {th }}$ century. The data originate from censuses so that they are not continuous time series. In order to have comparable data for an analysis at regional level, the scientists kept the administrative borders of the districts stable over the entire time period. The primary investigators added to the census data more detailed information by the Royal Prussian Statistical Office in additional years. The data are saved in several data files for each census year and additional for each special topic of the data. Thus, for example, for the census 1816 there are 8 files. In general, for all censuses there are 77 data files. The data are categorized into eight content areas: education, occupation, wages and income tax, industry, agriculture, population, religion, and miscellaneous. ${ }^{86}$ Finally, a merger file has been added containing information on merger variables which are needed to bring together several files of different censuses (Becker, Sascha O.; Cinnirella, F.; Hornung, E.; Woessmann, L. (2012), p. 6). In 1815, Prussia implemented a local government reorganisation and introduced the county level. Therefore, the census of 1816 covers 308 Prussian counties. The administrative structure was reformed in a way that a county's dimension follows the borders of the previously existing administrative units (Becker, Sascha O.; Cinnirella, F.; Hornung, E.; Woessmann, L. (2012), p. 7). Various administrative reforms followed and reshaped the county structure. Therefore,

\footnotetext{
84 Datafile: Becker, Sascha O.; Cinnirella, Francesco; Hornung, Erik; Woessmann, Ludger (2014): Die ifo Datenbank Preußische Wirtschaftsgeschichte (iPEHD). GESIS Datenarchiv, Köln. ZA8484 Datenfile Version 1.0.0, doi:10.4232/1.12140.

${ }^{85}$ Such as agriculture, industry, employment, population and wages.

${ }^{86}$ Containing information on surface area, buildings, municipalities, and residential areas.
} 
the number of counties changed and grew from 308 in 1816 to 574 in 1901. Most of these changes were divisions of one county into two or more counties. Therefore, "it is usually possible to reconstruct earlier administrative units by aggregating data from later years to the former structure" (Becker, Sascha O.; Cinnirella, F.; Hornung, E.; Woessmann, L. (2012), p. 7).

This data compilation is not accessible in histat. It can be ordered via the GESIS data service. ${ }^{87}$ Additionally, it is freely available at the Ifo Institute - Leibniz Institute for Economic Research at the University of Munich (www.cesifo-group.de/ipehd).

Potential uses and limitations of the data compilation: Although the data stem from historical censuses, the information provided in the database is of very high quality thanks to the accurate design and implementation of Prussia's statistical office. The database includes a large range of variables, including on education. In addition, the authors offer a detailed description on how to merge the data files of the censuses for intertemporal comparisons in their publication (Becker et al. 2012) and in the iPEHD internet-pages of the CESifo-web. Furthermore, a merge-county file is offered to support the merging procedure (available from GESIS-Data Archive as well as from the ifo Institute). This file contains information on the counties to enable the merging of different census files using the county as merge variable.

Still, as the authors caution, one has to be well acquainted with the underlying raw data in order to analyse and merge them accurately. The administrative changes over time induce a level of complexity which should not be overlooked. Therefore, careful usage of the data is very important.

\subsection{Some remarks on the analytic potential of the data}

The territorial focus of the offered data stock dealing with educational statistics on the German Reich and on Germany also indicates its limitation: it is not a cross-national data stock. The data type of statistical aggregate data makes comparisons more difficult the farther back in history the period of investigation of interest is located. Harmonized international time series on education history are not available due to different definitions of the collected issues and changing territorial boundaries. Thus, the studies providing time series data presented here give an insight into collective education and population processes for Germany. Therefore, historical developments and their causes, and the mutual dependence of structures can be analysed at the macro level with these data. This means that long series on education participation in Germany from 1800 can be used as an indicator for the degree of modernization of a society, or they can serve to describe education periods, with their phases of growth and stagnation (A. Nath, H. Titze, R. Metz ${ }^{88}$ ). In addition, time series provide the

87 Search and order the study via the Data Catalogue (DBK) on the web-page https://dbk.gesis.org/dbksearch/index.asp?db=e. Contact: datenservice.das@gesis.org or search via internet for doi:10.4232/1.12140.

${ }^{88}$ Nath, Axel (2001): Perioden des modernen Bildungswachstums. In: Apel, Hans J.; Kemnitz, Heidemarie; Sandfuchs, Uwe (eds.): Das öffentliche Bildungswesen. Historische Entwicklung, gesellschaftliche Funktionen, pädagogischer Streit. Bad Heilbrunn, p. 14-48.

Nath, Axel (2003): Bildungswachstum und äußere Schulreform im 19. und 20. Jahrhundert. In: Zeitschrift für Pädagogik, Vol. 49, No. 1, p. 8-25.

Titze, Hartmut (2004): Bildungskrisen und sozialer Wandel 1780-2000. In: Geschichte und Gesellschaft, Vol. 30, No. 2, p. 339-372. 
possibility to "categorize the present comparatively in the course of historical development" and to "explain historical developments by attempting to identify influencing factors and patterns of interaction between different development processes" (R. Metz, 2012, p. $32^{89}$ ). Examples of this include studies on the connection between demographic development and education processes ${ }^{90}$ or on the relationship between education and economic growth. ${ }^{91}$ Yet time series data cannot help us to address questions posed at the level of individual behaviour and individual attitudes, since the information content contained in these series is located at the macro level. Questions on the attitudes, behaviour and decisions of individuals in their respective social context can be addressed only by using individual data. For instance, one example of a question located at the individual level is a study by Peter Lundgreen, in which he analyses the individual educational and mobility opportunities of the population in two cities (Duisburg and Minden). ${ }^{92}$

There are various interlinking opportunities of the data compilations which have already been discussed in this article. In the context of the interlinking in a narrower sense of merging data of two data sets into a new working file in the case of aggregate data, it should be ensured that territory and investigation unit (for example students-population) are comparable. The reference to a uniform basis, the calculation of indices and quotas can help to harmonize long time series and to make them comparable.

The ifo-database on Prussian economic history offers elaborate possibilities to merge data of different census years by keeping the territory of investigation constant. The researchers developed identifier variables and a merge-county file to support the merging procedure.

The Data Handbooks on educational history are constructed in such a way that they subsequently connect to each other in terms of time periods and, if possible, in the data structure or rather in categories and disaggregations. ${ }^{93}$ But they refer to different territories, different pupils population, and different systems of education. Thus, for example, a comparison between pupils of Prussian higher schools and pupils of schools in the former Federal Republic of Germany (FRG) would compare mainly male students of the Prussian period with mixed pupils of the FRG period. The educational

Metz, Rainer (2006): 'Lange Wellen' im deutschen Bildungswachstum? In: Zeitschrift für Erziehungswissenschaft, Vol. 10, No. 7/2006, p. 15-51.

${ }^{89}$ Rahlf, Thomas; Metz, Rainer; Sensch, Jürgen; Franzmann, Gabriele; Suchi, Stefan; Noack, Andre; Witali, Mik (2012): histat - Zeitreihen zur Historischen Statistik von Deutschland online. GESIS - Technical Reports 2012/09. http://www.gesis.org/histat/docs/TechnicalReport_2012-09.pdf or http://www.ssoar.info/ssoar/handle/document/32599.

${ }^{90}$ Becker, Sascha O.; Cinnirella, Francesco; Woessmann, Ludger (2012): The effect of investment in children's education on fertility in 1816 Prussia. In: Cliometrica (2012) 6, S. 29-44. DOI 10.1007/s11698-011-0061-8.

Becker, Sascha O.; Cinnirella, Francesco; Woessmann, Ludger (2013): Does women's education affect fertility? Evidence from pre-demographic transition Prussia. In: European Review of Economic History, Vol. 17, No. 1, p. 24-44. doi: 10.1093/ereh/hes017.

${ }^{91}$ Diebolt, Claude; Litago, Javier (1997): Education and economic growth in Germany before the Second World War: an econometric analysis of dynamic relations. In: Historical Social Research, Vol. 22, No. 2, p. 132-149. URN: http://nbn-resolving.de/urn:nbn:de:0168-ssoar-32044.

${ }_{92}$ Lundgreen, P.; Kraul, M.; Ditt, K. (1988): Bildungschancen und soziale Mobilität in der städtischen Gesellschaft des 19. Jahrhunderts. Göttingen: Vandenhoeck \& Ruprecht.

${ }_{93}$ In Data Handbook volume II the researcher developed classifications for the school system of that period made them comparable. However, the data on schools of the German Empires' period cannot be compared unreserved with schools of higher education of the Federal Republic of Germany. The use of pupils ratio is necessary. The students statistics of higher education institutions of the German Empire and of the Federal Republic of Germany, on the other hand, offer the greatest potential of comparative analysis. Again, due to the territorial changes the students ratio should be used. 
system of schools at the time of the German Empire was different from the Federal Republics' school system, even if the school system of the Federal Republic of Germany emerged from the one of the German Empire. The calculation of quotas may offer valuable indicators of educational participation. Percentages help to facilitate a comparability of pupils' structure between the two periods. In the case of students of higher education there are better conditions to build long time series. Universities, technical universities and specialised institutions of higher education have a long tradition, reaching back to the time of the $19^{\text {th }}$ century. Information on students per higher education institution is collected for the respective territories ${ }^{94}$ and additionally for individual institutions ${ }^{95}$ as well as for individual fields of study and faculties. Therefore, in the case of the Data Handbooks Volume I and Volume VIII, part 2 the merging of the data into a new working file is possible. Again, student populations should be compared as the proportion of students among the like-aged population. On the other hand, in the case of the former German Democratic Republic (GDR), the deep system change at that time caused a radical break with the central characteristics of the traditional German hierarchical structured educational system. Vertical differentiations as well as regional differences have been eliminated. This makes comparisons with the period of the German Empire as well as with the federal three-tier school system of the FRG more difficult.

The data compilations by Claude Diebolt and the Data Handbook of F.R. Pfetsch offer the possibility to analyse the government funding of education and science and to associate the analysis with the institutional development of the educational system as well as with the use of educational institutions by pupils and students. Official expenditure per schools and per higher education institutions can be compared for example with indicators of educational success.

A small limitation is that information on the social origin is only available in the first volume of the Data Handbooks on Historical Education Research. Likewise, religious affiliation can only be offered by selected studies. Therefore, conclusions on the societal openness and structure cannot be made. Here again, the ifo-database on Prussia is an exception, because Prussia and its provinces created an elaborate statistics and the data are census data and not official school statistics. The statistics of the other German countries are much poorer in their quality.

Furthermore, selected population data have been added to each volume of the Data Handbooks on Historical Education Research. The comprehensiveness of the population data is adapted to the specific content of the educational statistics of the respective Data Handbook. This means that for example age categories are suited to the purposes for the calculation of pupils and students rates. They are not always disaggregated by gender or German regions in the case of the period of the German Empire. Depending on the quality of the time period, statistics on population are highly different in the individual countries of the German Empire. Here again, the most detailed information stems from Prussian official statistics and its provinces. It must be always taken into account that if a long period of 200 years should be analyzed, the researcher is faced with fundamental territorial changes and deep system breaks. These facts may cause jumps in the time series. Percentage calculation or indexing may help to analyze structures of the times series. However, this problem should be taken carefully into account.

\footnotetext{
94 i.e. the territory of the German Empire, Prussia, former Federal Republic of Germany or the German Democratic Republic, Germany in the borders after $3^{\text {rd }}$ October 1990, individual German countries.

${ }^{95}$ For example, the University of Berlin, of Breslau, of Cologne, of Jena, etc.
} 
Overall, the researchers compiled historical long term data for a period of about 200 years. The compilations cover a broad range of topics concerning the German educational system. The content of the data ranges from the development of the school system and the higher educational system, the development of careers in universities and in schools to official expenses on the educational system. Furthermore, statistics on the vocational school system have been gathered. In the case of the German school system in the period of the German Empire, extensive structural transformations, categories and classifications have been developed by the authors. These data cannot be found in the available sources. This also applies to the educational data of the former German Democratic Republic. The researchers partly collected the data from official statistical publication. Moreover, they went into archives to collect correct and additional information. The researcher tried to keep the categories of educational institutions as constant as possible over a long period. Therefore, for example, statistics on technical universities and universities have been gathered separately for the period of the Federal Republic of Germany, although the official statistics abolished the separation of these two institutions in 1972. By doing this, the researchers allow that these two time series can be traced back until the $19^{\text {th }}$ century. The analysis of the structural development and differentiation as well as of the use of educational institutions is also possible. The development of pupils and students flows can be analysed for the territories of the German Empire and Prussia, for Germany and its federal countries, and for individual institutions or institutional types. In the case of the Federal Republic of Germany, the change of higher education institutions can be analysed by means of the personnel statistics. The development of individual staff groups, the structure of personnel staff, and gender related developments can be examined.

\section{Study and data description, and study dissemination}

The following section deals with the integration of the above-mentioned studies into the research and download system histat. First, the preparation of the study description and the description of the study data are presented in a concise form. Then, the essential characteristics of the online-database histat with its research and download options are explained briefly.

\subsection{Study and data description}

The description of historical time series studies is divided into two parts:

First, a comprehensive description of the study is provided, containing information on the research question, territory and period of investigation, further methodological concepts (as, for example, used sources), as well as the researcher's publication in which he published and/or used his collected data.

Second, the subdivision of the study data is described by a list of data-tables. These data tables can be divided into sub-themes according to their thematic priority. For example, data of a study on academic careers can be divided into the sub-themes a) age structure of academic staff, b) doctoral exams at the university, and c) university students. Each sub-theme consists of several data-tables containing a set of time-series which can be combined under one table-heading. In the case of point a) (i.e., age structure of academic staff) one can choose the options Table a1) age structure of 
teaching staff for the field of study "medical science"; Table a2) age structure of teaching staff for the subject "Law"; etc.

This division of the data into sub-themes and the data table header are indicated in the study description and give the user an orientation for targeting the desired data. This is followed by a detailed description of the study data. The data are processed by using a standardized table format, which allows the integration of meta-data for each time series. The table header first provides information on the issue and on time-space-relation of the time series in form of the table title (for example: Population by gender and by German states, 1870-1930).

Subsequently, there is a description of the individual time series. In other words, information is displayed on the variable name, its categories and - if necessary - on further time-series subdivisions (e.g., variable name: population; categories: male, female; further subdivision: e.g. geographic area as the population by single German states = Bavaria, Prussia, etc.). A brief note on the primary sources used for the data-collection follows. Additionally, annotations on the data of the single time series are provided. They are important for the correct understanding of the meaning and statistical power of the time series data (for example, in the case of changing borders, they may refer to changing survey concepts and definitions of the official statistics, estimations by the investigator, etc.).

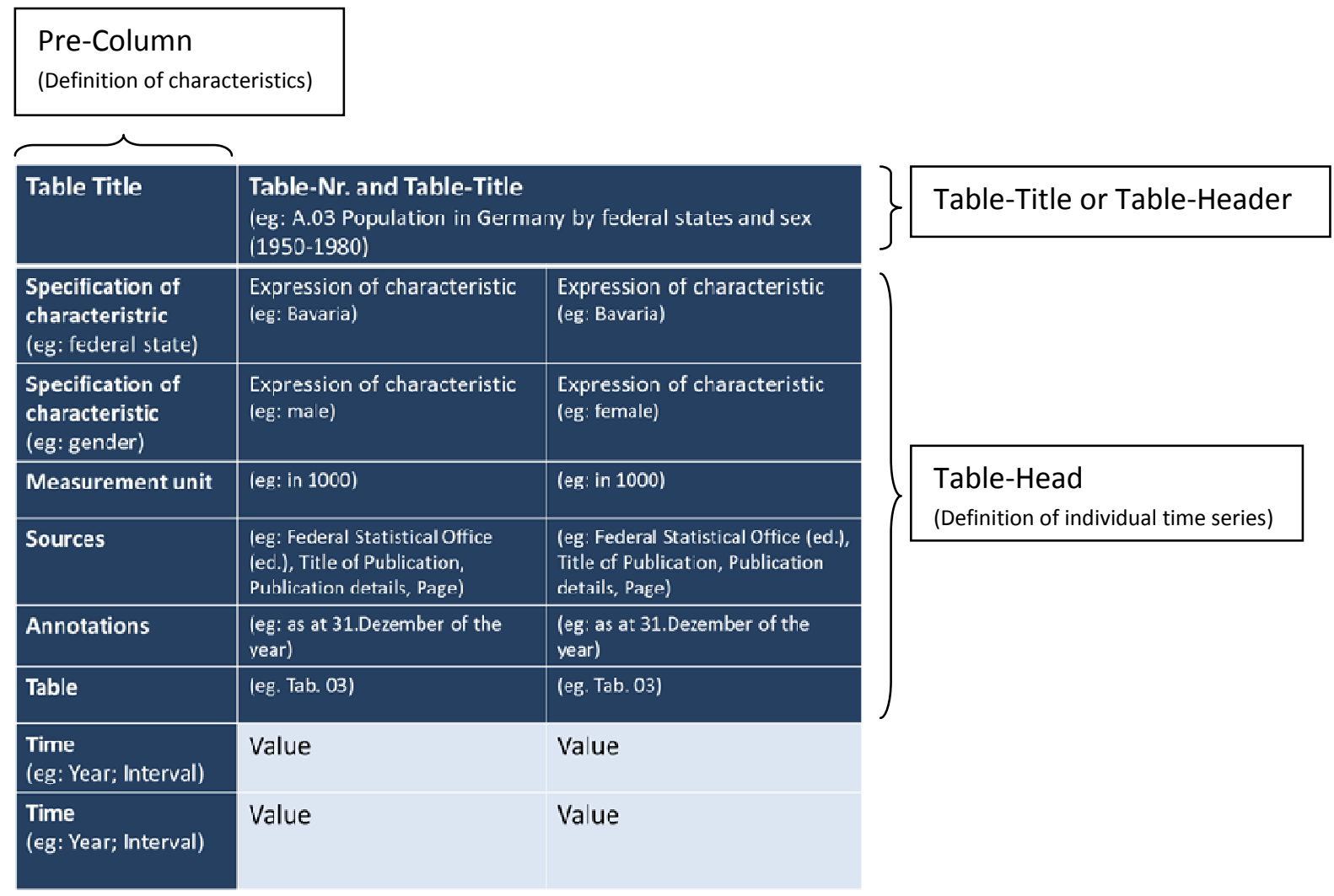

Figure 1: Labelling area of a data table in histat 


\subsection{Access to the data}

The database histat was developed in 2004 by GESIS. ${ }^{96}$ The aim of histat is to make time series from historical economic and social research accessible. Therefore, access should be as easy as possible. At the same time it is important that the presentation of the studies and data complies with scientific standards, i.e., data are always accessed in connection with the name of the researcher and his publication.

Time series can be found in histat by using three different menu items: a) the general research topic, (i.e. for example 'population', 'work', 'education', etc., by which the studies are categorized); b) the name of the primary researcher; and c) the time menu. Finally, there is the option of a study wide key word search (d) (see Figure 2).

The following figure shows the data selection and data access in the database histat

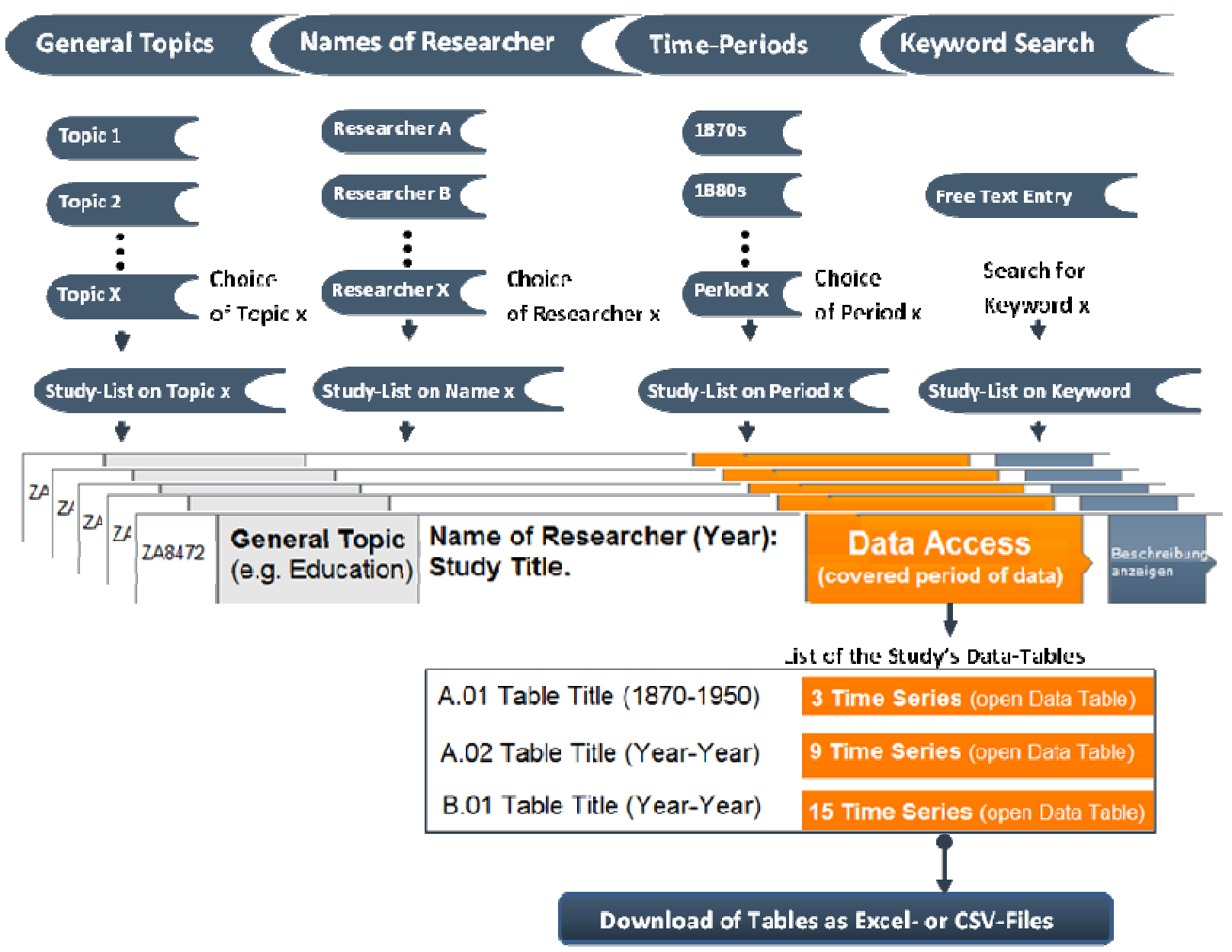

Figure 2: Data selection and data access in histat

\footnotetext{
${ }^{96}$ The project was funded by the GESIS-Leibniz Institute for the Social Sciences. The company data-quest in Göttingen received the assignment for the programming of histat.
} 


\section{a) Search by topics:}

At the beginning of the data import, an individual study is allocated to a certain higher-level topic (see Figure 3). Currently, there are 28 topics on offer, which are available under the menu item 'topics' (=Themen). After choosing a topic, a list of all studies on the chosen topic appears on the screen. Each single study is provided with two buttons, one which leads to the study description and the other leading to the study data.

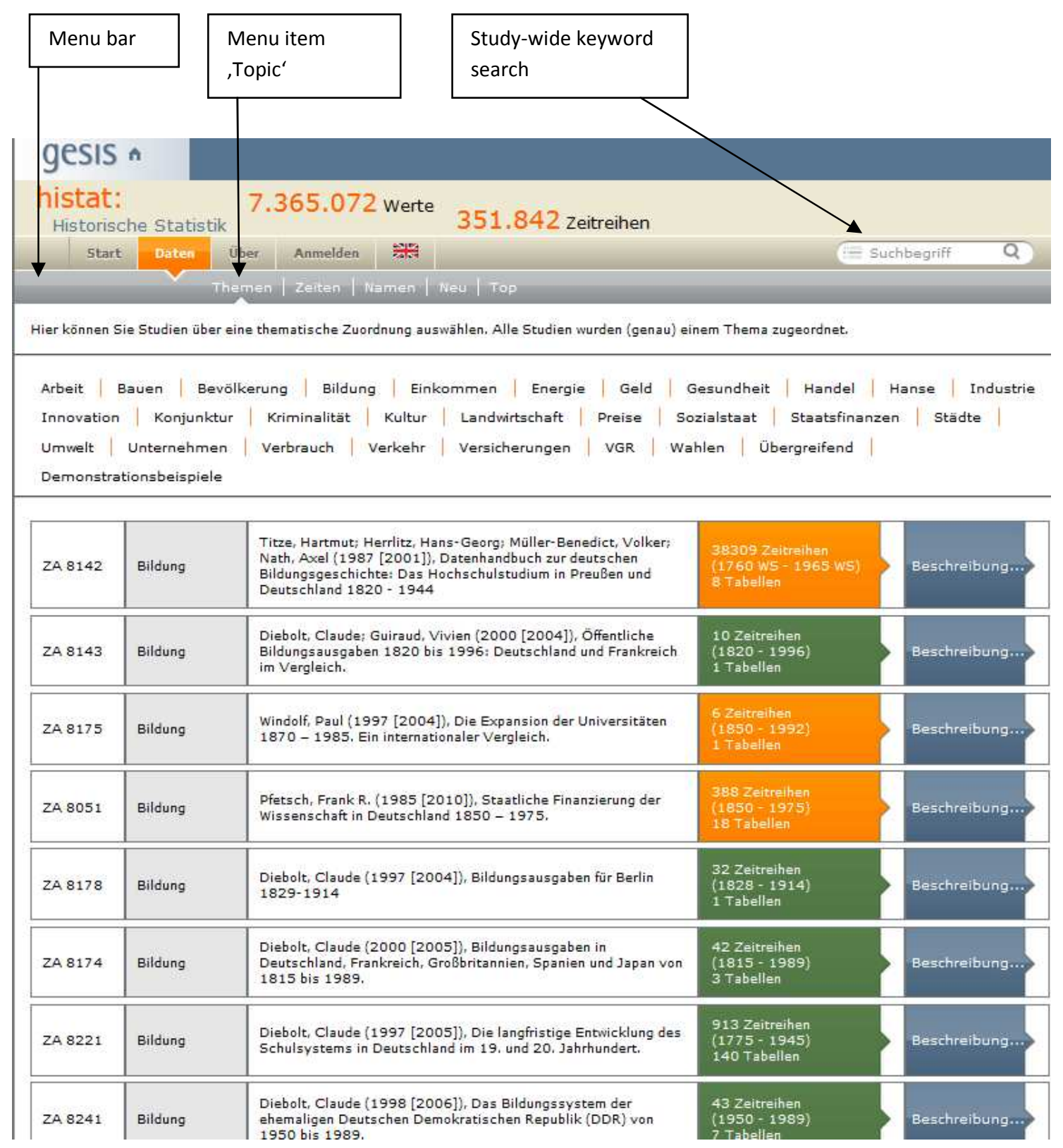

Figure 3: Menu item 'Topics': Top of the study list on the topic education (currently 28 studies) 
b) Search by the primary investigator's name:

Another access to the data is provided by the name of the researchers. Using an alphabetical list the user can choose a researcher's name. A list of the researcher's studies, imported into histat, appears and study data can be selected in the same way as described above.

c) Search by time-periods:

The menu point "time-periods" (=Zeiten) offers a choice of all studies for a selected time period. The result of a chosen period is - as with the other menu items - a list of studies which can be selected by pressing the 'description'-button or the 'time-series'-button.

The presentation of the studies is done in the same way in each of these three menus a), b) and c): each study is displayed as a bar containing the general topic, the researcher's name and the study title, the time-series button with information on the study's number of tables and time-series, and finally the study-description button (see Figure 4).

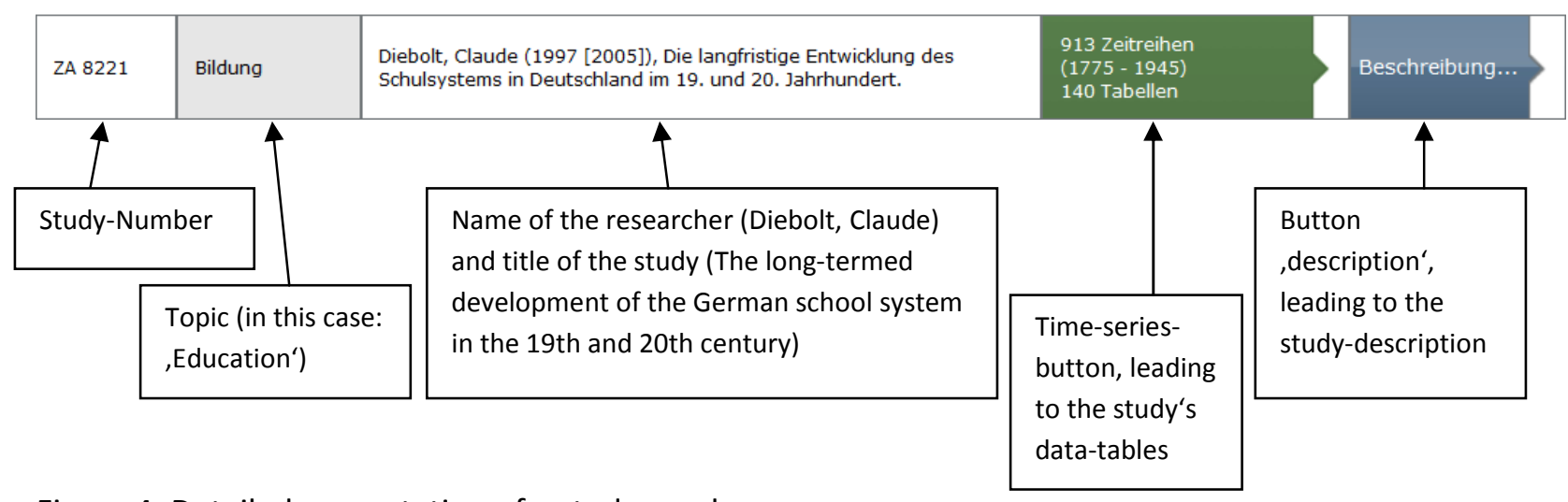

Figure 4: Detailed presentation of a study as a bar

d) Study-wide keyword-search:

The keyword search allows the user a flexible search for data (see Figure 5). The search range can be narrowed by choosing a general topic (for example 'education') and/or by defining a time-span. Furthermore, it can be determined whether it should be searched in the data-tables data-head and/or in the study-description. The result is, as in the other menus, a list of studies, each of them presented in the form of a bar. The 'time-series' button of the selected studies leads to the tables, containing time series dealing with the entered search term. 


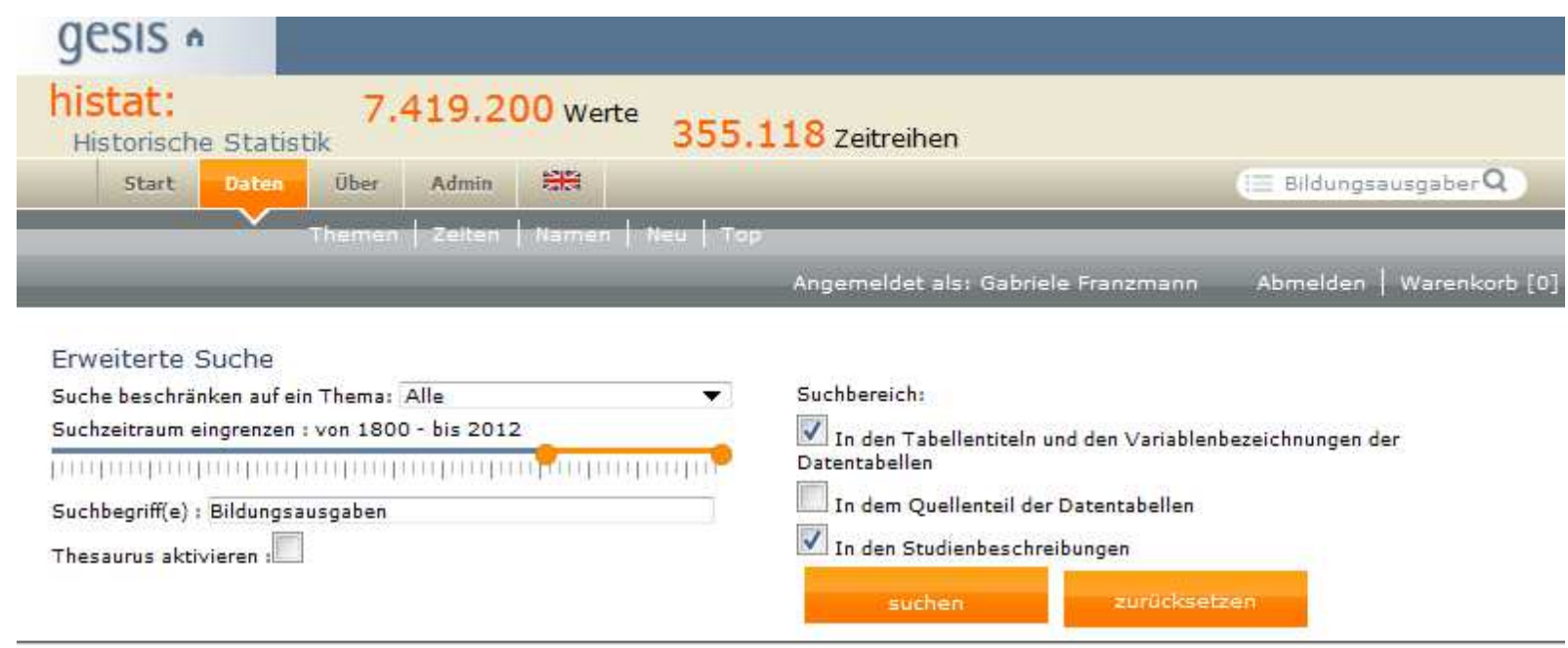

Suchergebnisse

9 Studien(n) mit Suchergebnissen:

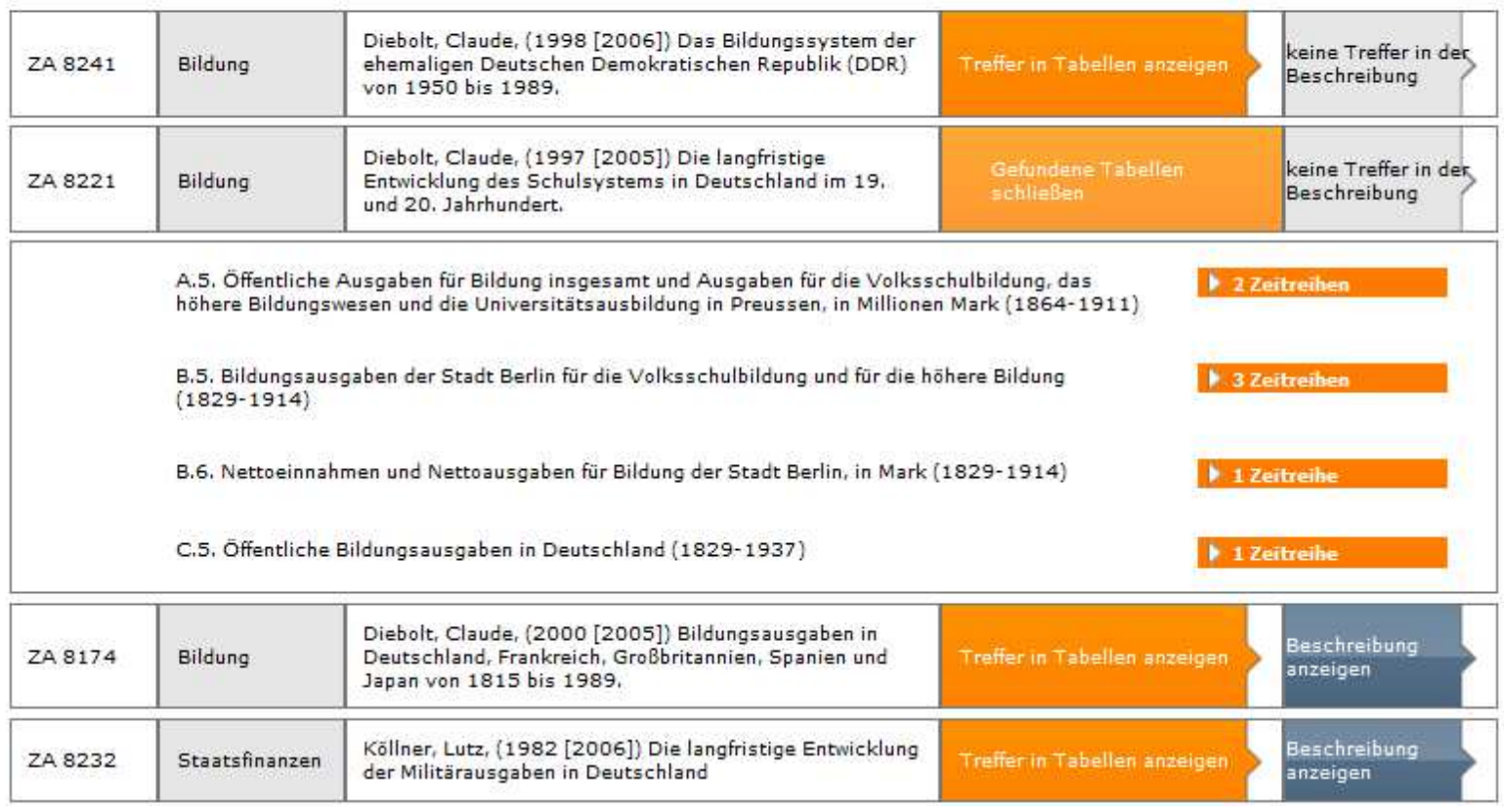

Figure 5: Menu of the study wide keyword search

In sum, the essential characteristics of the histat database can be summarized as follows:

Histat is hierarchically structured. All studies that are imported into histat are allocated to a subject area such as population or education.

Access to the data is given by the four menu items 'topics', 'names' (of the researchers), 'times', and 'keyword search'. The studies are always presented via a bar with information on the researchers name and the study title. This ensures that the data section of a study is always available in connection with the name of the primary researchers and his publication. Within the individual studies, the data are subdivided according to subtopics. 
Each study is comprehensively documented. This documentation is implemented by means of the study description, containing the study title, primary researcher, description of the study content, as well as the sources used and annotations for the entire study.

Supplementary material to the study is made available for download in the form of a PDF document. These PDFs usually provide very comprehensive annotations, source lists and methodology reports. The PDFs can be found at the study-description and can be downloaded by pressing a link.

The data section is prepared separately. Metadata are added to each time series, in which definitions, sources used, notes on the time series and, where necessary, on individual values are documented.

Histat allows the data export (free of charge) from an individual study as an Excel or text file. The exported files contain information on the publication. This information must be quoted if the data will be used for secondary analysis in the user's own publication. In addition, all metadata of the selected time series are exported, so that the data section is clearly defined and comprehensible.

\section{Exemplary studies}

The data handbooks and compilations discussed in this article open new opportunities for analysing long term developments of the German educational system. Various research questions can be investigated. For example, one can analyse overcrowding and shortage cycles in higher schools, higher education institutions, and in professions and the internal dynamics of educational growth. ${ }^{97}$ The institutional differentiation of the education system, the structures of university personnel and academic careers $^{98}$ can also be traced. Furthermore, one can study the relationship between

97 Titze, Hartmut (1984): Die zyklische Überproduktion von Akademikern im 19. und 20. Jahrhundert. In: Geschichte und Gesellschaft, Vol. 10, No. 1, p. 92-121.

Titze, Hartmut (1990): Der Akademikerzyklus. Historische Untersuchungen über die Wiederkehr von Überfüllung und Mangel an akademischen Karrieren. Göttingen: Vandenhoeck \& Ruprecht.

Titze, Harmut (2004): Bildungskrisen und sozialer Wandel 1780-2000. In: Geschichte und Gesellschaft, Vol. 30, No. 2, p. 339-372.

Müller-Benedict, Volker (1994): Die Dynamik des deutschen Hochschulsystems: 1820-1986. In: Historical Social Research / Historische Sozialforschung, Vol. 19, No. 2, p. 4-32.

Müller-Benedict, Volker (2000): Confirming long waves in time series of German student populations 18301990 using filter technics and spectral analysis. In: Historical Social Research / Historische Sozialforschung, Vol. 25, No. 3/4, p. 36-56.

Müller-Benedict, Volker (2002): Ist der Akademikermangel unvermeidbar? Müller-Benedict, Volker (2010): The Quantitative Development of Academic Careers in Germany 1850-1940: Growth, Exams and Age Structure. In: Historical Social Research / Historische Sozialforschung, Vol. 35, No. 3, p. 227-267.

Nath, Axel; Dartenne, Corinna M. (2008): Zur 'Eigendynamik' in den Langen Wellen des Bildungswachstums. Reziprozität zwischen Situations- und Diskursentwicklung. In: Crotti, Claudia und Fritz Osterwalder (Hrsg.): Das Jahrhundert der Schulreformen. Internationale und nationale Perspektiven, 1900-1950. Bern, Stuttgart, Wien: Haupt. S. 39-60.

${ }^{98}$ Müller-Benedict, Volker (2006): Wachstum und Austausch akademischer Karrieren 1850-1940. In: Zeitschrift für Erziehungswissenschaften, Vol. 9, No. 7/2006, p. 73-104.

Müller-Benedict, Volker (2010): The Quantitative Development of Academic Careers in Germany 1850-1940: Growth, Exams and Age Structure. In: Historical Social Research / Historische Sozialforschung, Vol. 35, No. 3, p. 227-267.

Nath, Axel; Dartenne, Corinna M. (2008): Zur 'Eigendynamik' in den Langen Wellen des Bildungswachstums. Reziprozität zwischen Situations- und Diskursentwicklung. In: Crotti, Claudia und Fritz Osterwalder (Hrsg.): Das 
education and economic growth, ${ }^{99}$ and the relationship between demography and education ${ }^{100}$. Finally, long-term development structures can be presented in detail using elaborate statistical methods, such as time series analysis or, partially, spatial regression analysis.

The following studies are based on the existing data compilations described in this text. The studies are examples for the interlinking of the data compilations and for the application of advanced statistical methods.

\subsection{Waves of educational growth}

In his methodological contribution on "Long Waves in German Education Growth"101, Metz addresses the question whether the growth of education in Germany over the last 200 years shows long term up- and downswings. To that end, he uses the data compilations of the "Data Handbooks on Historical Education Research" as the basis for his analysis. Using long time series of pupil ratios, high school graduates ratios, and university student ratios for a period of 200 years he tests the hypothesis of long waves. However, Metz points out that, in the context of trend adjustment of a time series, traditional methods of time series analysis may lead to artificial long term cycles by simultaneously underestimating the trend component. Therefore, he discusses the statistical effect of different filter techniques and shows that, for example, the so-called Kerbenfilter, which is often used for the analysis of cycles in the education area, causes a shift of phases. The author designs a structural stochastic time series model and applies it to the development of the selected indicators. To do this, he uses Andrew Harvey's method (see Metz 2006, pp. 31-46). The critical review of the author finally confirms the theory of Titze and Müller-Benedict of long waves in the growth of education for all analysed indicators.

Jahrhundert der Schulreformen. Internationale und nationale Perspektiven, 1900-1950. Bern, Stuttgart, Wien: Haupt. S. 39-60.

${ }^{99}$ Diebolt, Claude; Litago, Javier (1997): Education and economic growth in Germany before the second world war: an econometric analysis of dynamic relations. In: Historical Social Research, Vol. 22, No. 2, p. 132-149. URN: http://nbn-resolving.de/urn:nbn:de:0168-ssoar-32044.

Diebolt, Claude (2000): Die Erfassung der Bildungsinvestitionen im 19. und 20. Jahrhundert. Deutschland, Frankreich, Großbritannien und Spanien im Vergleich. In: Zeitschrift für Erziehungswissenschaft, Vol. 3, No. 4/2000, p. 517-538.

Diebolt, Claude; El Murr, Bachir (2004a): A Cobweb Model of Higher Education and Labour Market Dynamics. In: Brussels Economic Review - Chahiers Economiques de Bruxelles. Vol. 47, No. 3/4 Autumn - Winter 2004, p. 409-429.

Diebolt, Claude; El Murr, Bachir (2004b): Educational Development and Labour Markets. The Case of Higher Education in Germany, 1820-1941. In: Quality \& Quantity, Vol. 38, p. 127-145.

${ }^{100}$ Becker, Sascha O.; Cinnirella, Francesco; Woessmann, Ludger (2010): The Trade-off between Fertility and Education: Evidence from before the Demographic Transition. In: Journal of Economic Growth, Vol. 15, No. 3, p. 177-204.

Becker, Sascha O.; Cinnirella, Francesco; Woessmann, Ludger (2013): Does women's education affect fertility? Evidence from pre-demographic transition Prussia. In: European Review of Economic History, Vol. 17, No. 1, p. 24-44.

${ }^{101}$ Metz, Rainer (2006): „Lange Wellen“ im deutschen Bildungswachstum? Möglichkeiten und Grenzen moderner Zeitreihenanalyse. In: Zeitschrift für Erziehungswissenschaften, Vol. 9, No. 7/2006, p. 15-51. 


\subsection{Education and economic growth}

Diebolt and Litago ${ }^{102}$ analyse the relationship between public expenditure on education and national income in Germany before the Second World War. The data for their analysis come from Diebolt's data compilation on the long-term development of Germany's school system ${ }^{103}$ on the one hand and from Hoffmann's data on the development of the German economy ${ }^{104}$ on the other hand, both available in histat. ${ }^{105}$ Therefore, this analysis is an example of interlinking variables of two different data compilations for further investigations.

The focus of their analysis is on the dynamic consequences of education (measured as public expenditures on education) for economic growth (measured as national income) (Diebolt, Litago 1997, p. 132). In contrast to many articles from the literature, which were only able to consider a period of up to 20 years, the authors constructed a dataset that enable them to use a long-run perspective going back to the mid- $19^{\text {th }}$ century. Furthermore, their aim is to clarify the nature and limitations of their employed methods. Taking into account that social phenomena are very complex and that mathematical models are always simplifications of social reality, the authors use a battery of models as a safeguard against oversimplification. Any specific model would be a special case of the more complex model needed to get closer to reality.

In addition, Hoffmann's classic study of German economic growth contains long series on real growth, starting from 1850. However, the data series gives a distorted picture of real growth over this long period. Therefore, they must be weighted. Accordingly, the authors decided to weight the time series on expenditure assigning two-thirds to retail prices and one third to wholesale prices. Then, they split their study into three parts to test the assumption of a dynamic relationship between public expenditure on education and economic growth. First, they begin with the identification of the structure of the statistical series and the analysis of the degree of their integration. Subsequently, they use methods of spectral analysis to examine the inherent fluctuations in the statistical series. Finally, they test causality and look for possible co-integration relations (Diebolt, Litago 1997, p. 136).

In the context of the spectral analysis of the movements of German public expenditure on education and national income over a long period of time "the spectral density functions of the stationary series showed a cycle of 7.9 years in economic growth and a cycle of 8.7 years in public expenditure

\footnotetext{
102 Diebolt, Claude; Litago, Javier (1997): Education and economic growth in Germany before the second world war: an econometric analysis of dynamic relations. In: Historical Social Research, Vol. 22, No. 2, p. 132-149. URN: http://nbn-resolving.de/urn:nbn:de:0168-ssoar-32044.

${ }^{103}$ Datafile: Diebolt, Claude (2005): Die langfristige Entwicklung des Schulsystems in Deutschland im 19. und 20. Jahrhundert. GESIS Datenarchiv, Köln. histat. ZA8221 Datenfile Version 1.0.0, doi:10.4232/1.8221.

Publication: Diebolt, Claude (1997): L'évolution de longue période du système éducatif allemand: 19e et 20e siècles. Cahiers de l'ISMÉA. Économies et Sociétés. Série: Histoire quantitative de l'économie française. A.F. No. 23, 1997.

${ }^{104}$ Hoffmann, Walther G. (1965): Das Wachstum der deutschen Wirtschaft seit der Mitte des 19. Jahrhunderts. Springer-Verlag, Berlin. See also Data of this publication in GESIS-histat: Hoffmann, Walther G. (1965 [2007]): Das Wachstum der deutschen Wirtschaft seit der Mitte des 19. Jahrhunderts. Kapitel: Das Arbeits- und Kapitaleinkommen. GESIS Data Archive, Cologne. histat. ZA8257 Datafile Version 1.0.0, doi:10.4232/1.8257. Additional in histat: Hoffmann, Walther G.; Müller, Josef H.: Das Deutsche Volkseinkommen 1851-1957. Tübingen, Mohr, 1959.

Datafile: Hoffmann, Walther G.; Müller, Josef H. (1959 [2005]): Das deutsche Volkseinkommen in ausgewählten Bundesstaaten 1851-1913. GESIS Data Archive, Köln. histat. ZA8224 Datenfile Version 1.0.0, doi:10.4232/1.8224.

105 http://www.gesis.org/histat/
} 
on education. A 12.4 to 14.5 year movement was also observed in national income and one varying from 14.5 to 17.4 years in public expenditure on education" (Diebolt, Litago 1997, p. 141). This result seems to confirm the earlier work by Metz and Spree on growth of the German economy from 1820 to $1914^{106}$ as well as the work by Diebolt. ${ }^{107}$ The shifts in the periods result from the historical disturbances to which the economy and the socio-economic cycles are subjected to. They use various methods (such as cross-correlations, cospectra) to analyse the variables' dynamic relationship. They also employ causality tests which lead to the result of a causal impact of economic growth ${ }^{108}$ on education ${ }^{109}$ but they found no reciprocal causal relationship. This causal effect can be shown until 1945 (p. 141-143). A new situation arose after 1945, when the accumulation of human capital in the form of knowledge itself became the major driving force of growth.

\subsection{Children's education and fertility}

In "The effect of investment in children's education on fertility in 1816 Prussia" 110 Becker, Cinnirella and Woessmann analyse the interaction between the number of children and parental investment in children's education for Prussia. In this context they consider the year 1816, the period before the demographic transition and prior to the Industrial Revolution (Becker; Cinnirella; Woessmann 2012, p. 30). Their analysis relies on the compiled database of Prussian census data, i.e., the Database on Prussian Economic History (iPEHD). ${ }^{111}$ In order to carry out their investigations they merged the census in 1816,1819,1821, and 1849, using the Prussian counties as merge variable. The population censuses in 1816, 1821, and 1849 provide information on demography, education, religion, and livestock at the county level. Moreover, the census in 1819 contains data on establishments and means of production.

They find that there is a significant negative association between the education enrolment rate and the child-woman ratio in 1816. Additionally, they test to what extent preferences for children's education affect average annual fertility rates in the period from 1816 to 1821 . Subsequently, they also include a geographical reference in their analysis because the Prussian counties are the units of their observations. Therefore, they estimate spatial lag models and spatial error models which confirm that there is a significant negative effect of educational investment on fertility. The results of the spatial regression analysis show that the variables are positively spatially autocorrelated. In other words, counties that have high levels of fertility are surrounded by neighbouring counties with high fertility and vice versa. Furthermore, the negative relationship between investment in education and

\footnotetext{
${ }^{106}$ Metz, Rainer; Reinhard Spree (1981): „Kuznets-Zyklen im Wachstum der deutschen Wirtschaft während des 19. und frühen 20. Jahrhundert." In: Petzina, Dietmar; Roon, G. van (Eds.): Konjunktur, Krise, Gesellschaft. Wirtschaftliche Wechsellagen und soziale Entwicklung im 19. und 20. Jahrhundert. Klett-Cotta, Stuttgart. P. 343-376.

107 Diebolt, Claude (1994): L'évolution de longue période du système éducative allemand. Vol.1 : Education, croissance et cycles longs. Vol.2 : L'histoire quantitative de l'éducation. (PhD diss. in Economics, University of Montpellier I, 15 February 1994)

${ }^{108}$ Measured as , national income'.

${ }^{109}$ Measured as , public expenditure on education'.

${ }^{110}$ Becker, Sascha O.; Cinnirella, Francesco; Woessmann, Ludger (2012): The effect of investment in children's education on fertility in 1816 Prussia. In: Cliometrica, Vol. 6, No. 1, p. 29-44.

${ }^{111}$ Datafile: Becker, Sascha O.; Cinnirella, Francesco; Hornung, Erik; Woessmann, Ludger (2012 [2014]): Die ifo Datenbank Preußische Wirtschaftsgeschichte (iPEHD). GESIS Datenarchiv, Köln. ZA8484 Datenfile Version 1.0.0, doi:10.4232/1.12140.
} 
parental fertility is verified. The comparison of the results of parental fertility and parental investment in education between 1816 and 1849 shows a strong increase of the effect of school enrolment on fertility in 1849. This change may indicate that parents' preferences moved towards the priorities of the education of their children, which may be caused by technical and economic developments.

\section{Conclusion}

In this paper we have first presented some relevant background information on the origins of the histat project and the contents and suitability of the volumes compiled under the DFG supported project of the "Data Handbooks on Historical Education Research". Then, we have considered a number of technical aspects that are important when using the database online. Finally, we have presented some exemplary studies that show the wide range of research avenues that have already been explored on the basis of this database. At the same time, they also indicate the vast potential of these data for further research in the many education-related areas in the future. Therefore, they may significantly contribute to a large acceleration in our understanding of educational issues in Germany and elsewhere - until now, we have only begun to explore the tip of the iceberg.

The data compilations discussed in this article place the historical educational research for Germany on a statistical basis and facilitate detailed statistical analysis. The data have been collected in the framework of different research projects from various sources of the official statistics, archives of authorities or scientific publications. They have been processed in a user-friendly way and documented in detail. Furthermore, notes on data collection methodology have been provided by the researchers. In various cases systematisations have been developed and categories have been kept constant, which made it possible to report the statistical material in long constant time series. Offered via a uniform interface, they can be searched, downloaded and analysed. For historical research on German education this centralized access of research data is a crucial feature of the search and download system histat. On the basis of this database a wide range of topics concerning the development of the German education system can be analysed for a period of 200 years.

As demonstrated by the exemplary articles above, the data can be linked with variables of other data compilations available via the online database histat for the analysis of further research questions.

In this context, the research work by Diebolt on the one hand and by Becker, Cinnirella, and Woessmann on the other hand indicate the importance of spatial or regional comparisons on different levels. Interregional comparisons in long term perspective illustrate structures, processes and conditions in temporal progress under different circumstances. Development processes, their conditions and their diffusion in time and (historic) space can be worked out. This kind of analysis may help to understand today's societies, their institutional structures, and contemporary processes in their specific characteristics. ${ }^{112}$

112 However, interregional comparisons are a particular challenge for researchers, especially in the case of
historical long term statistics. First, the researcher is confronted with very different standards of survey
technics and statistical definitions of issues the more the statistical material goes back into the past. Problems
of making different national or county statistics comparable arise. Second, there are often lacks or breaks in 
Histat is an internet-platform offering the comfortable access to research data, archived in the GESIS Data Archive (GESIS-DAS). The content of histat is continually growing. However, the study data in histat concentrates mainly on the German territory. It would be a valuable advancement for the scientific community to develop a central internet portal which connects histat with other internet databases containing historical time series data. This would facilitate central search in and central access to the widespread research data on educational, social and economic history in histat and in other databases.

\section{Bibliography}

Albrecht, Ulrike; Kunz, Andreas (1990): Building a Databank on German Historical Statistics. In: Metz, Rainer; Van Cauwenberghe, Eddy; van den Voort, Roel (eds): Historical Information Systems. Leuven University Press, p. 77-86.

Becker, Sascha O.; Cinnirella, Francesco; Hornung, Erick; Woessmann, Ludger (2012): iPEHD - The ifo Prussian Economic History Database. CESifo Working Pater No. 3904. Category 5: Economics of Education. www.CESifo-group.org/wp.

Becker, Sascha O.; Cinnirella, Francesco; Woessmann, Ludger (2010): The Trade-off between Fertility and Education: Evidence from before the Demographic Transition. In: Journal of Economic Growth, Vol. 15, No. 3, p. 177-204.

Becker, Sascha O.; Cinnirella, Francesco; Woessmann, Ludger (2012): The effect of investment in children's education on fertility in 1816 Prussia. In: Cliometrica, Vol. 6, No. 1, p. 29-44.

Becker, Sascha O.; Cinnirella, Francesco; Woessmann, Ludger (2013): Does women's education affect fertility? Evidence from pre-demographic transition Prussia. In: European Review of Economic History, Vol. 17, No. 1, p. 24-44.

Becker, Sascha O.; Hornung, Erik; Woessmann, Ludger (2011): Education and Catch-up in the Industrial Revolution. In: American Economic Journal: Macroeconomics. Vol. 3, No. 3, p. 92-126.

Besser, Christoph (2008): histat-Datenkompilation online: Grunddaten der Bevölkerungsstatistik Deutschlands von 1871 bis 1939. GESIS Datenarchiv, Köln. histat. ZA8295 Datenfile Version 1.0.0, doi:10.4232/1.8295. Online publication at http://www.gesis.org/histat/.

Carpentier, Vincent; Diebolt, Claude (1999): "Public Expenditure on Higher Education in Germany and the United Kingdom after World War II", in: Historical Social Research. Vol. 24, n¹, 1999, pp. 187196.

Deissinger, Thomas (1999): Beruflichkeit als Zusammenhang. In Zeitschrift für Pädagogik. 40. Beiheft. S. 189-208.

time series, caused by historic events such as war, territorial changes, or simply by changes in survey methods. Therefore, statistical methods have to be applied to harmonize the individual long term time series. 
Diebolt, Claude 1995: Les indicateurs physiques du volume de l'éducation en France, in: Education et croissance économique: évolution de longue période et prospective. Union Européenne, Vol. 1. Carry, A./Diebolt, C.et al., September 1995, 4 vols., 1482 pages.

Diebolt, Claude (1997): L'evolution de longue période du système éducatif allemand: 19e et 20e siècles. Cahiers de I'ISMÉA. Économies et Sociétés. Série: Histoire quantitative de l'économie française. A.F. no. 23, 1997.

Diebolt, Claude (1999): Government Expenditure on Education and Economic Cycles in the Nineteenth Centuries. The Case of Spain with Special Reference to France and Germany, in: Historical Social Research, Bd. 24, Nr. 1, S. 3-31.

Diebolt, Claude (2000): Die Erfassung der Bildungsinvestitionen im 19. und 20. Jahrhundert. Deutschland, Frankreich, Großbritannien und Spanien im Vergleich. In: Zeitschrift für Erziehungswissenschaft, Vol. 3, No. 4/2000, p. 517-538.

Diebolt, Claude (2000a): Dépenses d'éducation et cycles économiques en Espagne aux XIX e et XX e siècles. In: Collection Logiques Economiques dirigée par Gérard Duthil, édition L'Harmattan, Paris, $\mathrm{S}$. 105-136.

Diebolt, Claude (2003): Accounting Expenditures on Education. Japan from Meiji Restoration to the Second World War. In: Historical Social Research, Vol. 28, No. 1/2, pp. 290-305.

Diebolt, Claude; Guiraud, Vivien (2000): Long Memory Time Series and Fractional Integration. A Cliometric Contribution to French and German Economic and Social History, in: Historical Social Research / Historische Sozialforschung (HSR), Vol. 15, No. 3/4, S. 4-22.

Diebolt, Claude; El Murr, Bachir (2004a): A Cobweb Model of Higher Education and Labour Market Dynamics. In: Brussels Economic Review - Cahiers Economiques de Bruxelles. Vol. 47, No. 3/4 Autumn - Winter 2004, p. 409-429.

Diebolt, Claude; El Murr, Bachir (2004b): Educational Development and Labour Markets. The Case of Higher Education in Germany, 1820-1941. In: Quality \& Quantity, Vol. 38, p. 127-145.

Diebolt, Claude; Litago, Javier (1997): Education and economic growth in Germany before the second world war: an econometric analysis of dynamic relations. In: Historical Social Research, Vol. 22, No. 2, p. 132-149. URN: http://nbn-resolving.de/urn:nbn:de:0168-ssoar-32044.

Franzmann, Gabriele (2015): The Online-Database histat as an Example for Research-Promoting Infrastructures for Studies in Quantitative Historical Research. In: Économies et Sociétés. Cahiers de I'ISMÉA. Série: histoire économique quantitative. AF no 50, Juin 2015. Pp. 821-856.

Hippe, Ralph; Baten, Jörg (2016). Geography, Land Inequality and Regional Numeracy in Europe in Historical Perspective, Working Paper.

Hoffmann, Walther G. (1965): Das Wachstum der deutschen Wirtschaft seit der Mitte des 19. Jahrhunderts. Springer-Verlag, Berlin.

Hoffmann, Walther G.; Müller, Josef H. (1959): Das Deutsche Volkseinkommen 1851-1957. Tübingen, Mohr. 
Huschner, Anke (2001): 'Geregelter' Zugang zum Abitur in den 1970er Jahren? In: Zeitschrift für Pädagogik, Volume 47, Issue 6, p.819-824

Köhler, Helmut; Rochow, Thomas (2013): Datenhandbuch zur Deutschen Bildungsgeschichte. Vol. IX: Schulen und Hochschulen in der Deutschen Demokratischen Republik 1949-1989. Göttingen: Vandenhoeck \& Ruprecht.

Lundgreen, Peter (2006): Historische Bildungsforschung auf statistischer Grundlage. Datenhandbücher zur deutschen Bildungsgeschichte. In: Zeitschrift für Erziehungswissenschaft, Vol. 10, No. 7/2006, p. 5-13.

Lundgreen, Peter (2011): Pädagogische Professionen. Ausbildung und Professionalität in historischer Perspektive. In: Helsper, Werner; Tippelt, Rudolf (Hrsg.): Pädagogische Professionalität. (Zeitschrift für Pädagogik, Beiheft 57) Weinheim: Beltz. S. 9-39.

Lundgreen, Peter; Köhler, Helmut, with Thomas Rochow and Jürgen Schallmann (2014): Vol. VII: Allgemein bildende Schulen in der Bundesrepublik Deutschland 1949 - 2010. Göttingen: Vandenhoeck \& Ruprecht.

Lundgreen, Peter; Kraul, Margret; Ditt, Karl (1988): Bildungschancen und soziale Mobilität in der städtischen Gesellschaft des 19. Jahrhunderts. Göttingen: Vandenhoeck \& Ruprecht.

Lundgreen, Peter; Schallmann, Jürgen (2013): Datenhandbuch zur Deutschen Bildungsgeschichte. Vol. XI: Die Lehrer an den Schulen in der Bundesrepublik Deutschland 1949-2009. Göttingen: Vandenhoeck \& Ruprecht.

Lundgreen, Peter; Scheunemann, Jana (2008): Datenhandbuch zur Deutschen Bildungsgeschichte. Vol. VIII: Berufliche Schulen und Hochschulen in der Bundesrepublik Deutschland 1949-2001. Teil 1: Berufliche Schulen. Göttingen: Vandenhoeck \& Ruprecht.

Lundgreen, Peter; Schwibbe, Gudrun (2008): Datenhandbuch zur Deutschen Bildungsgeschichte. Vol. VIII: Berufliche Schulen und Hochschulen in der Bundesrepublik Deutschland 1949-2001. Teil 2: Hochschulen. Göttingen: Vandenhoeck \& Ruprecht.

Lundgreen, Peter, with Gudrun Schwibbe and Jürgen Schallmann (2009): Datenhandbuch zur Deutschen Bildungsgeschichte. Vol. X: Das Personal an den Hochschulen in der Bundesrepublik Deutschland 1953-2005. Göttingen: Vandenhoeck \& Ruprecht.

Metz, Rainer (2006): „Lange Wellen“ im deutschen Bildungswachstum? Möglichkeiten und Grenzen moderner Zeitreihenanalyse. In: Zeitschrift für Erziehungswissenschaften, Vol. 9, No. 7/2006, p. 1551.

Metz, Rainer; Reinhard Spree (1981): „Kuznets-Zyklen im Wachstum der deutschen Wirtschaft während des 19. und frühen 20. Jahrhundert.“ In: Petzina, Dietmar; Roon, G. van (Eds.): Konjunktur, Krise, Gesellschaft. Wirtschaftliche Wechsellagen und soziale Entwicklung im 19. und 20. Jahrhundert. Klett-Cotta, Stuttgart. P. 343-376.

Müller, Detlef K. (1977): Sozialstruktur und Schulsystem. Aspekte zum Strukturwandel des Schulwesens im 19. Jahrhundert. Göttingen, Vandenhoeck \& Ruprecht. 
Müller, Detlef K.; Zymek, Bernd; Herrmann, Ulrich (1987): Datenhandbuch zur deutschen Bildungsgeschichte. Vol. II: Höhere und mittlere Schulen. Teil 1: Sozialgeschichte und Statistik des Schulsystems in den Staaten des Deutschen Reiches 1800-1945. Göttingen: Vandenhoeck \& Ruprecht.

Müller, Detlef K.; Hermann, Ulrich G.; Zymek, Bernd (2003): Datenhandbuch zur Deutschen Bildungsgeschichte. Vol. II: Höhere und mittlere Schulen. Teil 2: Regionale Differenzierung und gesamtstaatliche Systembildung. S. 149-461: Die Höheren Schulen für die männliche Bevölkerung im Staat Preußen und in den preußischen Provinzen 1832 - 1941. Göttingen: Vandenhoeck \& Ruprecht.

Müller-Benedict, Volker (1994): Die Dynamik des deutschen Hochschulsystems: 1820-1986. In: Historical Social Research / Historische Sozialforschung, Vol. 19, No. 2, p. 4-32.

Müller-Benedict, Volker (2000): Confirming long waves in time series of German student populations 1830-1990 using filter technics and spectral analysis. In: Historical Social Research / Historische Sozialforschung, Vol. 25, No. 3/4, p. 36-56.

Müller-Benedict, Volker (2002): Ist der Akademikermangel unvermeidbar? In: Zeitschrift für Erziehungswissenschaften, Vol. 5, No. 4/2002, p. 672-691.

Müller-Benedict, Volker (2006): Wachstum und Austausch akademischer Karrieren 1850-1940. In: Zeitschrift für Erziehungswissenschaften, Vol. 9, No. 7/2006, pp. 73-104.

Müller-Benedict, Volker (2010): The Quantitative Development of Academic Careers in Germany 1850-1940: Growth, Exams and Age Structure. In: Historical Social Research / Historische Sozialforschung, Vol. 35, No. 3, p. 227-267.

Müller-Benedict, Volker unter Mitarbeit von Jörg Janssen und Tobias Sander (2007): Datenhandbuch zur Deutschen Bildungsgeschichte. Vol. VI: Akademische Karrieren in Preußen und Deutschland 18501945. Göttingen: Vandenhoeck \& Ruprecht.

Nath, Axel (2001): Perioden des modernen Bildungswachstums. In: Apel, Hans J.; Kemnitz, Heidemarie; Sandfuchs, Uwe (eds.): Das öffentliche Bildungswesen. Historische Entwicklung, gesellschaftliche Funktionen, pädagogischer Streit. Bad Heilbrunn, p. 14-48.

Nath, Axel (2003): Bildungswachstum und äußere Schulreform im 19. Und 20. Jahrhundert. In: Zeitschrift für Pädagogik, Vol. 49, No. 1, p. 8-25.

Nath, Axel; Dartenne, Corinna M. (2008): Zur 'Eigendynamik' in den Langen Wellen des Bildungswachstums. Reziprozität zwischen Situations- und Diskursentwicklung. In: Crotti, Claudia und Fritz Osterwalder (Hrsg.): Das Jahrhundert der Schulreformen. Internationale und nationale Perspektiven, 1900-1950. Bern, Stuttgart, Wien: Haupt. S. 39-60.

Pfetsch, Frank R. (1974): Zur Entwicklung der Wissenschaftspolitik in Deutschland 1750 - 1914. Berlin: Duncker \& Humblot.

Pfetsch, Frank R. (1985): Datenhandbuch zur Wissenschaftsentwicklung. Die staatliche Finanzierung der Wissenschaft in Deutschland 1850 - 1975. 2nd edition. Köln: Zentrum für historische Sozialforschung e.V. 
Rahlf, Thomas; Metz, Rainer; Sensch, Jürgen; Franzmann, Gabriele; Suchi, Stefan; Noack, Andre; Witali, Mik (2012): histat - Zeitreihen zur Historischen Statistik von Deutschland online. GESIS Technical Reports 2012/09. http://www.gesis.org/histat/docs/TechnicalReport_2012-09.pdf or http://www.ssoar.info/ssoar/handle/document/32599.

Sensch, Jürgen (2008): histat-Datenkompilation online: Bevölkerungsstand, Bevölkerungsbewegung, Haushalte und Familien in der Bundesrepublik Deutschland 1947 bis 1999. GESIS Datenarchiv, Köln. histat. ZA8200 Datenfile Version 1.0.0, doi:10.4232/1.8200. Data compilation available via histat: http://www.gesis.org/histat/.

Titze, Hartmut (1990): Der Akademikerzyklus. Historische Untersuchungen über die Wiederkehr von Überfüllung und Mangel an akademischen Karrieren. Göttingen: Vandenhoeck \& Ruprecht.

Titze, Hartmut (2004): Bildungskrisen und sozialer Wandel 1780-2000. In: Geschichte und Gesellschaft, Vol. 30, No. 2, p. 339-372.

Titze, Hartmut; Herrlitz, Hans-Georg; Müller-Benedict, Volker; Nath, Axel (1987): Datenhandbuch zur deutschen Bildungsgeschichte. Vol. I: Hochschulen. Teil 1: Das Hochschulstudium in Preußen und Deutschland 1820 - 1944. Göttingen: Vandenhoeck \& Ruprecht.

Titze, Hartmut; Herrlitz, Hans-Georg; Müller-Benedict, Volker; Nath, Axel (1995): Datenhandbuch zur deutschen Bildungsgeschichte. Vol. I: Hochschulen. Teil 2: Wachstum und Differenzierung der deutschen Universitäten 1820 - 1944. Göttingen: Vandenhoeck \& Ruprecht. 